\title{
HISTORIA
}

http://dx.doi.org/10.15633/sts.3527

KS. JAN SZCZEPANIAK

Studia Sandomierskie

WHiDK UPJP2, Kraków

$26(2019)$

\section{SZKOLA PARAFIALNA W KRAŚNIKU W OKRESIE STAROPOLSKIM}

Badacze sądzą, że początków królewskiego miasta Kraśnik, lokowanego na prawie polskim, przy trakcie biegnącym z Opatowa na Ruś, należy doszukiwać się na przełomie XIII i XIV w. We władaniu władców miasto pozostawało do czasu panowania króla Ludwika Węgierskiego. Wystawił on 26 lipca 1377 r. dokument nadający miasto Kraśnik wraz z 3 wsiami (Stróżą, Wyżnicą i połową Rzeczycy) oraz zamkiem i ośmioma osadami wiejskimi braciom Dymitrowi (podskarbiemu Królestwa) i Iwanowi, dziedzicom wsi Klecie koło Biecza. Równocześnie tymże aktem włączył nadane miasteczko, wsie i osady pod prawo niemieckie ${ }^{1}$.

Najprawdopodobniej pierwszy kościół w Kraśniku powstał na początku XIV w. Wcześniej mieszkańcy mogli korzystać z kościoła parafialnego pw. NMP w Stróży, bądź z kościoła filialnego w Grębienicy². Pierwsza informacja o funkcjonowaniu parafii pochodzi z 1403 r. Wówczas Beata, wdowa po Dymitrze z Goraja, nadała kościołowi pw. św. Pawła wieś Rzeczycę. Plebanem kraśnickim był Marcin s. Klosmana. W połowie XV w. sytuacja parafii zarządzanej przez duchowieństwo diecezjalne musiała być na tyle ustabilizowana prawnie i finansowo, że ok. 1448 r. Tęczyńscy nie tylko rozpoczęli budowę murowanego kościoła, ale do czasu przybycia zakonników dwukrotnie przebudowywali wznoszony budynek, z zamiarem jego powiększenia i upiększenia ${ }^{3}$.

1 H. Grocholski, Wokót początków Kraśnika, w: Z dziejów powiatu kraśnickiego, pod red. K. Myślińskiego i J. J. Szaflika, Lublin 1963, s. 28; F. Kiryk, Z badań nad urbanizacją Lubelszczyzny w dobie jagiellońskiej, „Rocznik Naukowo-Dydaktyczny. Prace Historyczne” 1972, z. 43, s. 106, 137-138; J. Chachaj, Zarys dziejów parafii Popkowice do początków XVII w., „Archiwa, Biblioteki i Muzea Kościelne” (dalej: ABMK) 110 (2018), s. 96-97.

2 F. Kiryk, Z badań nad..., art. cyt., s. 137-138.

3 S. Kuraś, Słownik historyczno-geograficzny województwa lubelskiego w średniowieczu, w: Dzieje Lubelszczyzny, t. 3, pod red. M. Wawrzyniaka, Warszawa 1983, s. 114; H. Landecka, Kościót parafialny pod wezwaniem Wniebowzięcia Najświętszej Maryi Panny w Kraśniku - nowe ustalenia badawcze po I etapie badań - 2008-2009, „Budownictwo i Architektura” 7 (2010), s. 53-66. 
Kanoników regularnych z Krakowa sprowadził do Kraśnika kasztelan wiślicki i starosta sandomierski Jan z Rabsztyna Tęczyński. Dokument fundacyjny prepozytury przeznaczonej dla kanoników wystawił on 18 maja 1468 r. Fundację zatwierdził 13 marca 1469 r. biskup krakowski Jan Lutkowic z Brzezia, a 9 kwietnia 1487 r. papież Innocenty VIII ${ }^{4}$. Dokument fundacyjny oraz biskupi dyplom zatwierdzający fundację określały wzajemne relacje pomiędzy macierzystym klasztorem w Kazimierzu k. Krakowa a klasztorem filialnym w Kraśniku, które podkreślały konieczność zachowania w nowym klasztorze statutów obowiązujących w Krakowie i zwyczajów życia zakonnego tamże wypracowanych, w tym form życia liturgicznego ${ }^{5}$.

Ważne miejsce w posłudze duszpasterskiej kanoników regularnych zajmowała troska o kształcenie, bowiem nauczanie i wychowanie było nieodłączną częścią zadań podejmowanych przez wspólnoty kanonickie ${ }^{6}$. Przy każdym zakładanym klasztorze prowadzili oni szkołę i bibliotekę7. Wiemy, że pod koniec XV w. nie było w Polsce od tej zasady odstępstwa. Szkoły były we wszystkich klasztorach kanonickich: Kłobucku, Kazimierzu, Kraśniku, Kurozwękach i Mstowie ${ }^{8}$. Skoro w dokumentach fundacyjnych mocno wyartykułowano zasadę, że dyscyplina klasztorna i duszpasterstwo miały się we wszystkim wzorować na zasadach obowiązujących w kazimierskim klasztorze, należy domniemywać, że dotyczyło to również kwestii prowadzenia przez kanoników szkoły parafialnej ${ }^{9}$. Krótko jej dzieje omówił ks. prof.

4 W. Bielak, Okoliczności fundacji klasztoru kanoników regularnych w Kraśniku, ABMK 108 (2017), s. 17-27; T. Graff, Klasztor w Kraśniku w dziełach Jana Dtugosza, ABMK 108 (2017), s. 99-110.

5 E. Zielińska, Fidelia Fideis. Klasztor Kanoników Regularnych w Kraśniku a klasztor Kanoników Regularnych w Kazimierzu w drugiej połowie XV i pierwszej połowie XVI wieku, w: Klasztor Bożego Ciała Kanoników Regularnych Laterańskich w Krakowie w okresie przedtrydenckim. Ludzie - wydarzenia - budowle - kultura, red. K. Łatak, Łomianki 2012, S. 369-370.

6 H. D. Wojtyska, Duchowość Kanoników Regularnych, „Saeculum Christianum” 3 (1996), nr 1, s. 129.

7 Ł. Kapera, Nauczanie parafialne w Mstowie w czasach staropolskich i podczas zaborów, w: Mstów. Miasto - klasztor - parafia na przestrzeni wieków, red. K. Łatak, Łomianki 2013, s. 37; K. Łatak, Kongregacja krakowska kanoników regularnych laterańskich na przestrzeni dziejów, Kraków 2002, s. 80; K. Łatak, S. Nalbach, Ze studiów nad kultura umysłowa kanoników regularnych krakowskiej prepozytury Bożego Ciała w XV i XVI wieku, Kraków 2009, s. 157-158; K. Łatak, Szkoty parafialne kanoników regularnych laterańskich w Małopolsce w czasach staropolskich, „Nasza Przeszłość” 117 (2012), s. 360-361.

8 K. Łatak, Szkoty parafialne..., art. cyt., s. 361, 368-369, 371, 376-377; I. Podedworny, Nauczanie $w$ klasztorze kanoników regularnych $w$ Mstowie na przełomie średniowiecza i czasów nowożytnych, w: Przemijanie i trwanie. Kanonicy Regularni Laterańscy w dawnej i współczesnej Polsce, red. K. Łatak, I. Makarczyk, Kraków 2008, s. 453-455.

9 K. Łatak, Prepozyci prepozytury kraśnickiej kanoników regularnych laterańskich od fundacji do reformy w 1628 roku, ,Saeculum Christianum” 24 (2014), s. 139-140. 
Kazimierza Łataka CRL w artykule prezentującym szkoły parafialne prowadzone przez kanoników w Małopolsce (Kazimierz, Kłobuck, Kraśnik, Wolbrom, Kurozwęki, Sucha Beskidzka) ${ }^{10}$.

\section{Źródła do dziejów szkoły parafialnej w Kraśniku}

Badania dotyczące szkolnictwa parafialnego w okresie staropolskim nie należą do łatwych, z powodu niewielkiej bazy źródłowej i lakoniczności istniejących zapisów. Jak pisał wspomniany wyżej ks. prof. Kazimierz Łatak CRL: „Szkoły parafialne nie pozostawiły bowiem własnych archiwaliów, a jeśli na szczątki takich natrafia się tu i ówdzie, to sięgają one dopiero XVIII w. Bazę źródłową do dziejów szkół parafialnych w czasach staropolskich trzeba więc było tworzyć w szeroko zakrojonych kwerendach, obejmujących różnorodny i rozdrobniony materiał, jak chociażby akta konsystorskie, wizytacje biskupie, akta rektorskie Almae Matris Cracoviensis [Uniwersytet Jagielloński], akta grodzkie, księgi miejskie, kroniki, zapisy testamentowe, rękopisy i druki szkolne, etc." ${ }^{11}$.

Niewątpliwie do najważniejszych źródeł do dziejów szkoły kraśnickiej należą protokoły wizytacji biskupich archidiakonatu zawichojskiego, do którego wchodził dekanat urzędowski, z parafią w Kraśniku. Do dyspozycji badaczy w Archiwum Kurii Metropolitalnej w Krakowie jest osiem wizytacji, a w Archiwum Archidiecezji Lubelskiej - jedna. W Krakowie przechowywane są następujące akta wizytacji: (1.) akta wizytacji archidiakonatu zawichojskiego przeprowadzonej w 1592 r. przez Andrzeja z Żarnowca, wikariusza kolegiaty sandomierskiej, z polecenia archidiakona zawichojskiego Marcina Szyszkowskiego (ordynariuszem krakowskim był wówczas kard. Jerzy Radziwiłł) ${ }^{12}$; (2.) akta wizytacji archidiakonatu zawichojskiego przeprowadzonej w 1598 r. z polecenia kard. Jerzego Radziwiłła (archidiakonem zawichojskim był wówczas Marcin Szyszkowski) ${ }^{13}$; (3.) akta wizytacji archidiakonatu zawichojskiego przeprowadzonej w 1617 r. przez Jakuba Piaseckiego, dziekana kieleckiego i kanonika poznańskiego z polecenia bp. Marcina Szyszkowskie$\mathrm{go}^{14}$; (4.) akta wizytacji archidiakonatu zawichojskiego przeprowadzonej w $1637 \mathrm{r}$.

${ }^{10}$ K. Łatak, Szkoły parafialne..., s. 351-380. Istnieją również prace o szkołach parafialnych w Kazimierzu, Kłobucku, Truskolasach i Mstowie. K. Łatak, S. Nalbach, Ze studiów nad kultura umystowa..., dz. cyt., s. 157-174; Ł. S. Kapera, Nauczanie parafialne w Mstowie..., art. cyt., s. 31-58; Ł. S. Kapera, Szkolnictwo i opieka społeczna u Kanoników Regularnych Laterańskich obediencji kłobuckiej, ,Veritati et Caritati” 5 (2015), s. 269-281; I. Podedworny, Nauczanie $w$ klasztorze kanoników regularnych $w$ Mstowie na przełomie średniowiecza i czasów nowożytnych, w: Przemijanie i trwanie. Kanonicy Regularni Laterańscy w dawnej i wspótczesnej Polsce, red. K. Latak, I. Makarczyk, Kraków 2008, s. 451-464.

11 K. Łatak, Szkoty parafialne..., art. cyt., s. 353.

12 Archiwum Kurii Metropolitalnej w Krakowie (dalej: AKMKr), sygn. AV 1, k. 33-36v.

13 AKMKr, sygn. AVCap. 12, k. 10-12.

14 AKMKr, sygn. AVCap. 34, k. 12-15v. 
z polecenia bp. Jakuba Zadzika, przez Aleksandra Jana Brzeskiego, archidiakona zawichojskiego, dziekana włocławskiego, kanonika krakowskiego i scholastyka sandomierskiego ${ }^{15}$; (5.) akta wizytacji archidiakonatu zawichojskiego przeprowadzonej w 1682 r. z polecenia bp. Jana Małachowskiego ${ }^{16}$; (6.) akta wizytacji archidiakonatu zawichojskiego przeprowadzonej w 1689 r. przez Krzysztofa Dębickiego, archidiakona i oficjała sandomierskiego oraz prepozyta Stopnickiego, z polecenia bp. Jana Małachowskiego ${ }^{17}$; (7.) akta wizytacji archidiakonatu zawichojskiego przeprowadzonej w latach 1718 i 1719 przez Mikołaja Złotnickiego, kanonika lwowskiego oraz archidiakona i oficjała sandomierskiego, z polecenia bp. Kazimierza Łubieńskiego ${ }^{18}$; (8.) akta wizytacji archidiakonatu zawichojskiego przeprowadzonej w 1748 r. przez Cypriana Józefa Langiego, archidiakona zawichojskiego, kanonika sandomierskiego i prepozyta Rakowskiego, z polecenia bp. Andrzeja Stanisława Załuskiego ${ }^{19}$. W Lublinie znajdują się akta wizytacji dekanatów chodelskiego, urzędowskiego i kazimierskiego z 1781 r. przeprowadzonej przez Franciszka Dunin Kozickiego, dziekana kolegiaty pilickiej, z polecenia bp. Kajetana Ignacego Sołtyka ${ }^{20}$.

Pozyskując z nich i interpretując informacje, trzeba jednak pamiętać o specyfice tego typu źródeł. Najważniejszą ich cechą jest brak jednolitych zasad w sporządzaniu protokołu wizytacyjnego. Nawet jeżeli wizytator był zaopatrzony w instrukcję i kwestionariusz pytań, nie zawsze ściśle stosował się do nich. Często informacje zawarte w wizytacjach, szczególnie w tych najstarszych, są schematyczne. Pomijano w nich zagadnienia uznane za mało ważne. Bywa, że w obrębie tego samego tomu, zawierającego protokoły $\mathrm{z}$ wizytacji przeprowadzonej $\mathrm{w}$ jednym czasie i przez jednego wizytatora, brakuje jednorodności, a pomijane informacje dotyczą zasadniczych kwestii. Działo się tak, jak wszystko wskazuje, ponieważ powszechną praktyką było, że wizytator w protokole nic nie zapisywał, jeśli pleban pytany był o sprawę lub rzecz nieistniejącą w jego parafii.

Szczególnie uwidacznia się to w informacjach dotyczących szkolnictwa. Do rzadkości należą protokoły, gdzie znajdziemy komplet wiadomości na temat budynku szkolnego, nauczyciela, uczniów, programów nauczania. Nie zawsze oznacza to złą kondycję instytucji. Zazwyczaj jest to efekt traktowania szkoły jako zagadnienia mało istotnego dla życia parafii. Ważniejszym dla wizytatora był stan kościoła i zabudowań plebańskich, dbałość o majątek funduszowy, dochody parafii, zakres duszpasterstwa zwyczajnego, kondycja moralna duchowieństwa niż istnienie szkoły oraz poziom jej prowadzenia. Lakoniczność zapisów o szkole uniemożliwia rozstrzygnięcie wielu kwestii. Czy notatka o złym stanie budynku szkolnego jest różnoznaczna z tym, że w parafii był zatrudniony nauczyciel i w miarę regularnie odbywa-

15 AKMKr, sygn. AVCap. 44, s. 32-39.

16 AKMKr, sygn. AV 12, k. 91-95.

17 AKMKr, sygn. AVCap. 66, k. 48-54.

18 AKMKr, sygn. AVCap. 58, s. 51-53.

19 AKMKr, sygn. AV 45, k. 182v-186.

20 Archiwum Archidiecezjalne Lubelskie (dalej: AAL), sygn. Rep. A 105, k. 670-689. 
ły się lekcje? Czy nakaz uporządkowania lub budowy nowego budynku szkolnego świadczy o tym, że szkoła nie funkcjonowała? Przecież nauka szkolna mogła się odbywać w chylącym się ku upadkowi budynku lub w szpitalu, wikarówce lub w samych zabudowaniach klasztornych.

Ważną część informacji o klasztorze kraśnickim oraz szkole parafialnej, nauczycielach i uczniach pozyskano ze źródeł proweniencji zakonnej ${ }^{21}$. W materiałach przechowywanych w archiwum klasztoru Bożego Ciała w Krakowie przydatne do napisania tego tekstu dane odnaleziono w nekrologach, w których poza informacjami o zmarłych kanonikach klasztorów krakowskiej kongregacji, odnotowano wiadomości dotyczące klasztoru i miasta Kraśnika ${ }^{22}$. Pomocą do nakreślenia dziejów konwentu kraśnickiego były również wiadomości zawarte $\mathrm{w}$ aktach kapituł generalnych ${ }^{23} \mathrm{i}$ protokołach wizytacji zakonnych ${ }^{24}$. W archiwum parafii farnej w Kraśniku pomocą w opisaniu dziejów miasta $\mathrm{w}$ drugiej połowie XVIII w. były notatki znajdujące się w księdze ochrzczonych $^{25}$, a do ustalenia nazwisk nauczycieli wpisy do księgi bractwa różańcowego ${ }^{26}$.

W najstarszych aktach konsystorza lubelskiego, zdeponowanych w Archiwum Archidiecezjalnym w Lublinie, odszukano nazwiska nauczycieli szkoły kraśnickiej. Zapisy te są najstarszymi wzmiankami potwierdzającymi funkcjonowanie szkoły w mieście ${ }^{27}$.

W zasobach Archiwum Państwowego w Lublinie znajdują się akta miasta Kraśnika. W XVI i XVII w. w księgach miejskich odnaleziono także nazwiska nauczycieli szkoły parafialneje ${ }^{28}$.

${ }^{21}$ Kwerendę w archiwach zakonnych przeprowadził ks. prof. Kazimierz Łatak CRL, inspirator napisania tego teksu. Serdecznie dziękuję mu za przekazanie tych materiałów i za zgodę na wykorzystanie ich w tekście.

22 Archiwum Klasztoru Bożego Ciała Kanoników Regularnych Laterańskich w Krakowie (dalej: $\mathrm{ABC}$ ), Memoriale fratrum et benefactorum defunctorum Congregationis Canonicorum Regularium Lateranensium, b. sygn.; ABC, Cathalogus fratrum defunctorum Canonicorum Regularium Lateranensium Congregationis Cracoviensis ab introductione Cracoviam scilicet ab anno 1405 conscriptus cui accedit, b. sygn.

23 ABC, Acta Capituli Generalis Conventus Sacratissimi Corporis Christi Casimiriae ad Cracoviam Canonicorum Regularium Sancti Augustini (1628-1779), b. sygn.

24 ABC, Liber visitationum conventuum (1692-1697), b. sygn.

25 Archiwum Parafii Farnej w Kraśniku (dalej: APKr), sygn. U 1629-1670, Metrica baptisatorum ecclesiae collegiatae Conventus Crasnicensis Canonicorum Regularium Lateranensium post deflagrationem eiusdem ecclesiae 1735, 3 junii,

26 APKr, Księga Archikonfraterni Różańca Najświętszej Maryi Panny w kościele kraśnickim Canonicorum Regularium Lateranensium erygowanej pod tytułem Wniebowzięcia tejże Królowej po zgorzeniu pomnienionego kościoła sporządzona a dla pomnożenia chwały Boskiej, honoru Maryi i pożytku żywych i umarłych. Otworzona roku 1736, dnia 27 maja, b. sygn.

27 AAL, sygn. Off. Lub. 2, Acta consistorii foranei Lublinensis dioecesis Cracoviensis (1452-1466); AAL, sygn. Off. Lub. 4, Acta consistorii foranei Lublinensis dioecesis Cracoviensis (1465-1480). Informacje te zawdzięczam również ks. prof. Kazimierzowi Łatakowi.

28 Archiwum Państwowe w Lublinie (dalej: APL), Akta miasta Kraśnika (dalej: AMK), 


\section{Początki szkoły parafialnej w Kraśniku}

Pierwsze znane nam informacje o szkole parafialnej w Kraśniku, zapisano krótko po osiedleniu się w niej kanoników regularnych, znajdujemy w Liber beneficiorum Jan Długosza ${ }^{29}$. W Liber beneficiorum diecezji krakowskiej napisał: „Item est in eodem oppido schola, cuius rectorem praepositus coenobii de Crasznik pro tempore constituit, et solariat eundem anno quolibet quinque marcis" ${ }^{30}$. W czasie redagowania tego zapisu prepozytem w Kraśniku był Jan z Piekar (1473/1474-1497). Zgodnie z zapisem Długosza wypłacał on nauczycielowi miejscowej szkoły 5 grzywien rocz$n^{31}{ }^{31}$. „Magistrem” szkoły był wówczas Michał, którego imię odnotowano w aktach konsystorza foralnego w Lublinie z powodu toczonego przez niego sporu z proboszczem ostrowskim Leonardem (zapis z 1 września 1473 r.) oraz Janem, klerykiem z Kraśnika (zapis 7 października 1473 r.) ${ }^{32}$.Te lakoniczne wzmianki nie pozwalają jednak rozstrzygnąć czasu powstania szkoły.

Pośrednim potwierdzeniem funkcjonowania szkoły w połowie XV w., przed przejęciem parafii przez kanoników laterańskich, jest wzmianka w aktach konsystorza lubelskiego zapisana 7 sierpnia 1453 r. o procesie, jaki wytoczył wikariusz kraśnicki Piotr notariuszowi miejskiemu o tymże samym imieniu. Notariusz Piotr otrzymał od wikariusza suknię z czarnego sukna za przepisanie księgi. Ponieważ pracę wykonał niestarannie, został pozwany przez ks. Piotra przed sąd oficjała lubelskiego. Być może pozwany notariusz miejski był również rektorem szkoły, na co wskazuje późniejsza praktyka łączenia obu tych funkcji ${ }^{33}$.

Na to, że w Kraśniku kanonicy, przejmując parafię, zastali już szkołę, wskazuje również powszechność istnienia w drugiej połowie XV w. szkół w miastach, a także we wsiach kościelnych Małopolski, Wielkopolski, Mazowsza i Prus Królewskich. Funkcjonowanie szkół w miastach i we wsiach kościelnych nie było wyjątkiem,

sygn. 2, [Księga wójtowsko-ławnicza i burmistrzowsko-radziecka] (1558-1748); APL, AMK, sygn. 7, Acta controversiarum officii advocatialis et scabinalis (1606-1611); APL, AMK, sygn. 8, [Księga wieczysta wójtowsko-ławnicza], 1608-1647. Akta miasta Kraśnika z lat 1550-1807 w formie cyfrowej zostały upublicznione w Internecie: https://szukajwarchiwach.pl/35/40/0/1\#tabZespol [dostęp: 16 XII 2019 r.].

29 E. Zielińska, Kultura intelektualna kanoników regularnych z klasztoru $w$ Kraśniku $w$ latach 1469-1563, Lublin 2002, s. 44-46; A. Karbowiak, Dzieje wychowania i szkót w Polsce w wiekach średnich, t. 2, Petersburg 1903, s. 55; T. Gliński, Kanonicy regularni (bożeciołki) w opinii Dlugosza, w: Studia z dziejów Kościoła Bożego Ciała w Krakowie, red. Z. Jakubowski, Kraków 1977, s. 201; S. Kot, Szkolnictwo parafialne w Małopolsce XVI-XVIII w., Lwów 1912, s. 230.

${ }^{30}$ Joannis Dlugossii senioris canonici Cracoviensis Opera omnia, t. 9, Liber beneficiorum dioecesis Cracoviensis nunc primum e codice autographo editus, t. 3, Monasteria, opr.

A. Przeździecki, Kraków 1864, s. 174.

31 K. Łatak, Prepozyci prepozytury..., dz. cyt., s. 145.

32 AAL, sygn. Off. Lub. 4, k. 211, 217, 221; K. Łatak, Prepozyci prepozytury..., dz. cyt., s. 145.

33 AAL, sygn. Off. Lub. 2, k. 56v. 
lecz regułą ${ }^{34}$. Było to efektem znanego w całej Europie procesu rozwoju szkolnictwa. „Przyczyny tego zjawiska - jak pisał Stanisław Litak - były różnorodne: religijno-kulturalne, ekonomiczne, a nawet polityczne. Najogólniej mówiąc, można wskazać na dwie: zmiany w Kościele oraz umocnienie się państwa. Ważna była zwłaszcza ta pierwsza. Wzrost wystawności liturgicznej w Kościele, stanowiącej środek przybliżenia religii szerokim masom ludności, pociągał za sobą zapotrzebowanie na świecką służbę pomocniczą. Od XV w., a zwłaszcza od XVI w. datuje się zwyczaj angażowania chłopców, jako ministrantów (do tego czasu funkcję sprawowali duchowni) i wykonawców śpiewu kościelnego, co wymagało jakiegoś przynajmniej elementarnego kształcenia. Stało się to jedną z ważnych przyczyn rozwoju szkolnictwa parafialnego" ${ }^{35}$. Znane i szeroko komentowane prace mówiące o polskim szkolnictwie parafialnym w XV i pierwszej połowie XVI w. Antoniego Karbowiaka $^{36}$, Eugeniusza Wiśniewskiego ${ }^{37}$, Józefa Nowackiego ${ }^{38}$ nie pozostawiają wątpliwości, że prawie przy każdej polskiej parafii przed reformacją istniała szkoła. $\mathrm{W}$ archidiakonacie lubelskim w drugiej połowie XV w., zgodnie z ustaleniami Władysława Frocha, szkoły funkcjonowały w 34, a może i w 40 parafiach z 59 istniejących (ok. od 58\% do 68\%). Szkoły były w pobliskim Urzędowie, Batorzu i Wilkołazie) $)^{39}$. Trudno przypuścić, że nie było jej w Kraśniku, którym zarządzali, podobnie jak Batorzem, Tęczyńscy ${ }^{40}$.

W metryce Uniwersytetu Krakowskiego pierwszego studenta z Kraśnika, nie licząc proboszcza tejże parafii ks. Marcina z Lublina ${ }^{41}$, odnajdujemy dopiero w semestrze zimowym 1477 r. Był nim Piotr, syn Mikołaja (de Crasnyk), późniejszy lektor teologii przy kościele Bożego Ciała w Krakowie ${ }^{42}$. Do 1508 r. na studiach w Krakowie pojawiło się jeszcze dwóch studentów pochodzących z Kraśnika: w 1486 r.

34 S. Litak, Sieć szkół parafialnych w Rzeczpospolitej w XVI i pierwszej połowie XVII w. Próba posumowania, „Rozprawy z Dziejów Oświaty” 37 (1996), s. 21-22; E. Wiśniowski, Parafia w średniowiecznej Polsce. Struktura i funkcje społeczne, Lublin 2004, s. 279-281.

35 S. Litak, Edukacja początkowa w polskich szkołach w XIII-XVIII wieku, Lublin 2010, s. 47.

36 A. Karbowiak, Dzieje wychowania ..., dz. cyt.

37 E. Wiśniowski, Rozwój organizacji parafialnej w Polsce do czasów reformacji, w: Kościół w Polsce, t. 1, Średniowiecze, red. J. Kłoczowskiego, Kraków 1966, s. 333-346; E. Wiśniowski, Sieć szkół parafialnych $w$ Wielkopolsce i Małopolsce w początkach XVI w., „Roczniki Humanistyczne” 15 (1967), z. 2, s. 87-105.

38 J. Nowacki, Dzieje archidiecezji poznańskiej, t. 2, Archidiecezja poznańska w granicach historycznych i jej rozwój, Poznań 1964.

39 W. Froch, Dzieje szkoły lubelskiej przy kościele parafialnym św. Michała w XV-XVIII w., Lublin 1999, s. 13-14.

40 S. Kuraś, Słownik historyczno-geograficzny..., dz. cyt., s. 25, 114-115.

${ }_{41}$ Marcin z Lublina, syn Klosmana, rector ecclesie in Crassnik, wpisał się do metryki uniwersyteckiej w 1402 r. Metryka Uniwersytetu Krakowskiego z lat 1400-1508, wyd. A. Gąsiorowski, T. Jurek, I. Skierska przy współpr. R. Grzesika, t. 1-2, Kraków 2004, s. 50, nr [02/071].

42 Metryka Uniwersytetu..., dz. cyt., s. 394, nr [77h/151]. 
Mikołaj, syna Grzegorza (de Krassznyk) ${ }^{43}$, a w 1505 r. Andrzej, syna Stanisława ${ }^{44}$. Powszechną praktyką w okresie staropolskim (do końca XVIII w.) było uzyskiwanie wykształcenia elementarnego w pobliżu miejsca zamieszkania lub indywidualnie w domu rodzinnym. W podróż w poszukiwaniu wykształcenia i wiedzy udawano się zazwyczaj po zakończeniu elementarnej nauki ${ }^{45}$.

Żadnego natomiast studenta z Kraśnika nie odnotowano w metryce uniwersyteckiej z lat 1509-1551. Jak sądzi ks. prof. K. Łatak, świadczy to o tym, że „albo szkoła funkcjonowała słabo, albo mieszczan nie stać było na dalsze kształcenie synów" ${ }^{\prime 46}$. W pierwszej połowie XVI w. szkoła jednak istniała, co potwierdza powizytacyjne zalecenie bp. Jana Konarskiego oraz zapis w księdze beneficjów z 1529 r. W trakcie wizytacji biskup nakazał, by kanonicy z Kraśnika ograniczyli liczbę służących z dwóch do jednego. Od przełomu XIV i XV w. przepisy zakonne umożliwiały posiadanie przez profesów służących, rekrutujących się spośród uczniów szkół prowadzonych przy klasztorach. Zwyczaj ten na trwałe zagościł w klasztorze kraśnickim, skoro w trakcie wizytacji w 1598 r. przeprowadzonej z mandatu kard. Jerzego Radziwiłła, wizytator zezwolił na posiadanie przez każdego kanonika po jednym służącym rekrutującym się z uczniów ${ }^{47}$. W opisie beneficjów diecezji krakowskiej z 1529 r. odnotowano, że rektor szkoły za swoją pracę pobierał od prepozyta 6 grzywien ${ }^{48}$.

\section{Szkoła w okresie potrydenckim}

Za czasów prepozyta Jana Pomorzańskiego (1561-1580) szkoła w mieście działała. Jej absolwentami mogli być pochodzący z Kraśnika kandydaci do święceń kapłańskich: Wojciech, s. Leonarda (prezbiterat 2 kwietnia 1575) ${ }^{49}$, Marcin, s. Wojciecha (prezbiterat 26 maja 1584) s0 $^{50}$ Jan Orłowic CRL, s. Jana (prezbiterat 7 kwietnia 1601) ${ }^{51}$, Adam CRL, s. Wojciecha (prezbiterat 17 marca 1601) ${ }^{52}$, Zygmunt CRL,

${ }_{43}$ Metryka Uniwersytetu..., dz. cyt., s. 459, $\mathrm{nr}$ [86h/262].

44 Metryka Uniwersytetu..., dz. cyt., s. 618, nr [1505h/175].

45 J. Szczepaniak, Duchowieństwo diecezji krakowskiej w XVIII w. Studium prozopograficzne, Kraków 2010, s. 172-174.

46 Metryka czyli album Uniwersytetu Krakowskiego z lat 1509-1551, wyd. A. Gąsiorowski, T. Jurek, I. Skierska, przy współpr. R. Grzesika, Warszawa 2010; K. Latak, Szkoły parafialne..., art. cyt., s. 372.

47 AKMKr, sygn. AVCap. 12, k. 11

48 Księga dochodów beneficjów diecezji krakowskiej z roku 1529 (tzw. „, Liber Retaxationum”), wyd. Z. Leszczyńska-Skrętowa, Kraków 1968, s. 455-456; K. Latak, Prepozyci prepozytury..., dz. cyt., s. 150.

49 AKMKr, sygn. Eo 1, k. 45v; Księgi egzaminów do święceń $w$ diecezji krakowskiej z lat 1573-1614, opr. i wst. opatrzył Z. Pietrzyk, Kraków 1991, s. 89, nr [399].

50 AKMKr, sygn. Eo 1, k. 156; Księgi egzaminów..., dz. cyt., s. 298, nr [3313].

51 AKMKr, sygn. Eo 3, k. 152; Księgi egzaminów..., dz. cyt., s. 245, nr [2589].

52 AKMKr, sygn. Eo 3, k. 143; Księgi egzaminów..., dz. cyt., s. 62, nr [19]. 
s. Mikołaja (diakonat 29 marca 1608) ${ }^{53}$ i Mikołaj OFMObs., s. Szymona (akolitat 18 września 1609$)^{54}$.

Pierwsza większa wzmianka mówiąca o szkole pochodzi z 19 czerwca $1592 \mathrm{r}$. W tymże dniu, na zlecenie archidiakona zawichojskiego Marcina Szyszkowskiego, odbyła się wizytacja klasztoru i parafii. Szkoła parafialna działała, jej budynek był murowany. Wizytujący zwrócił jednak uwagę, że szkoła pokryta była starym dachem. Rektor ze stopniem bakałarza artium miał wielu uczniów, a uczył ich pobożności, obyczajów oraz sztuk wyzwolonych. Spośród książek używanych w szkole wizytator wymienił Colloquia Erazma z Rotterdamu ${ }^{55}$.

Dach musiano rychło po wizytacji naprawić, skoro w protokole po wizytacji przeprowadzonej w 1598 r. odnotowano, że budynek szkolny był dobrze utrzymany. Szkoła była znaczna i zapewne dobrze działała, ponieważ nauczyciel pobierał 24 floreny, a klasztor zapewniał mu codzienne utrzymanie ${ }^{56}$.

Pośrednim dowodem na funkcjonowanie szkoły w Kraśniku na przełomie XVI i XVII stulecia są uczący się w Akademii Zamojskiej kraśniccy mieszczanie. W pierwszej ćwierci XVII w. w gronie zamojskich studentów odnajdujemy pochodzących z tego miasta Andrzeja Zakościelnego, s. Józefa, Jana Kempkowica, s. Wojciecha i Wojciecha Kucharskiego, s. Jana. Pierwszy z nich zapisał się na studia w 1605 r. Zapewne nauki początkowe odbyli oni w szkole kanoników w rodzinnej miejscowości. Liczba kraśniczan uczących się w Zamościu zapewne była większa, ale z zasady w albumie studentów, przy osobach pochodzenia plebejskiego, nie zapisywano miejscowości pochodzenia ${ }^{57}$.

W 1617 r. w protokole wizytacyjnym potwierdzono istnienie murowanego i dobrze utrzymanego budynku szkolnego, zawierającego dwie izby z trzema komorami. Jedna z nich służy dla kierownika szkoły, druga dla uczenia młodzieży ${ }^{58}$.

Dziesięć lat później, w trakcie prepozytury Alberta Sowińskiego z Tarnowa, sytuacja w szkole nie uległa zmianie, skoro po wizytacji klasztoru, kościoła i szkoły w aktach Kapituły Generalnej nie odnotowano żadnej uwagi ${ }^{59}$.

Wczesną wiosną w 1637 r. odbyła się kolejna wizytacja kanoniczna, zarządzona przez bp. Jakuba Zadzika. W dekanacie urzędowskim przeprowadził ją Jan Karol Nerwicz, promotor fiscalis w kancelarii zadwornej ordynariusza oraz proboszcz w Dobrowodzie. Po kilkudziesięciu latach od wybudowania szkoła nie zrobiła na

53 AKMKr, sygn. Eo 3, k. 316; Księgi egzaminów..., dz. cyt., s. 390, nr [4571].

54 AKMKr, sygn. Eo 3, k. 341; Księgi egzaminów..., dz. cyt., s. 351, nr [4023].

55 AKMKr, sygn. AV 1, k. 33-36v.

56 AKMKr, sygn. AVCap. 12, k. 11.

${ }^{57}$ H. Gmitek, Album studentów Akademii Zamojskiej 1595-1781, Warszawa 1994, s. 52, 182; H. Gmitek, Młodzież z woj. lubelskiego Akademii Zamojskiej (1595-1781). Próba ujęcia statystycznego, „Res Historica” 17 (2004), s. 147-149.

58 AKMKr, sygn. AVCap. 34, k. 34; S. Kot, Szkolnictwo parafialne..., dz. cyt., s. 230.

59 ABC, Acta Capituli Generalis Conventus Sacratissimi Corporis Christi Casimiriae ad Cracoviam Canonicorum Regularium Sancti Augustini (1628-1779), b. sygn., k. 3v. 
wizytatorze korzystnego wrażenia. Uznał, że nie jest dostatecznie uporządkowana. Ówczesny prepozyt ks. Jan Chrzciciel Malanowski obiecał, że w krótkim czasie budynek zostanie odnowiony ${ }^{60}$. Była to jedyna krytyczna uwaga wizytatora. W uwagach końcowych sprawozdania wizytacyjnego napisał: „Widać, że dzięki wyjątkowej trosce i działaniom Wielebnego Jana Malanowskiego, aktualnego prepozyta, zarówno służba, jak i wyposażenie kościoła, obowiązki i dyscyplina zakonna widoczne są na każdym miejscu. Pozostaje tylko powierzyć trosce prowizorów, bardziej zalecając niż rozkazując, by szkoła została zorganizowana w lepiej przystosowanym ku takim działaniom budynku"61.

Szkolnictwo parafialne w Polsce w okresie reformy potrydenckiej przeżywało okres świetności. Przyczyniła się do tego poreformacyjne zainteresowanie sprawami wiary oraz potrzeba umocnienia tożsamości katolickiej w kontekście istnienia wielkich i mocnych intelektualnie wspólnot różnowierczych. Troska o wychowanie i nauczanie młodzieży w czasach panowania Stefana Batorego, Zygmunta III Wazy i Władysława IV Wazy uwidaczniała się w dekretach synodów oraz innych aktach kościelnych ${ }^{62}$. W diecezji krakowskiej wielki wpływ na ożywienie życia religijnego i wychowanie młodzieży miały opublikowane w $1601 \mathrm{r}$. List pasterski bp. Bernarda Maciejowskiego, opracowana w 1612 r. przez wykładowców Akademii Krakowskiej, na zlecenie bp. Piotra Tylickiego i zaakceptowana przez synod, ustawa szkolna oraz postanowienia synodów krakowskich: bp. B. Maciejowskiego (23 maja 1601 r.), bp. P. Tylickiego (3 maja 1612 r.) i bp. M. Szyszkowskiego (10 lutego 1621 r.).

Statuty synodu z $1601 \mathrm{r}$. zostały ogłoszone przez bp. P. Tylickiego. W sprawach nauczania i wychowania dokument zobowiązywał plebanów i prepozytów do głoszenia w kościele parafialnym kazań w niedziele i święta, a także przy każdej nadarzającej się okazji kazań katechetycznych o modlitwie oraz przykazaniach Bożych i kościelnych. Zachęcał rządców parafii do wizyt domowych w okresie Bożego Narodzenia oraz kontrolowania uczęszczania do szkół dzieci oraz katechezy szkolnej i domowej ${ }^{63}$.

Drugi synod za rządów bp. P. Tylickiego (1612) sprawy nauczania i wychowania dzieci i młodzieży poruszył w drugim statucie. Poza dbałością o sprawy religijne polecał troszczyć się o nauki świeckie, „aby zaniedbane a tak pożyteczne dla Kościoła nauki jak: muzyka, arytmetyka i inne sztuki wyzwolone na powrót do szkoły wróciły i młodzież należycie mogła być chowana" ${ }^{64}$. Dołączone do statutów wspomniane wyżej ustawy szkolne zwracały uwagę, że szkoła parafialna będzie dobrze funkcjonowała, jeżeli zaistnieją do tego trzy czynniki, zgodnie ze sobą współ-

60 AKMKr, sygn. AVCap. 44, k. 33.

${ }^{61}$ AKMKr, sygn. AVCap. 44, k. 38-39.

62 J. Krukowski, Z dziejów szkolnictwa parafialnego Krakowa w okresie Odrodzenia, Kraków 1986, s. 102-105.

63 B. Kumor, Dzieje diecezji krakowskiej do 1795, t. 2, Kraków 1999, s. 148; S. Nasiorowski, „List pasterski” kard. Bernarda Maciejowskiego, Lublin 1992.

${ }^{64}$ Cyt. za: S. Kot, Szkolnictwo parafialne ..., dz. cyt., s. 39. 
pracujące: pobożność, kierownictwo i sposób uczenia. Pobożności mieli się uczyć uczniowie na katechezie, podczas kazań, biorąc czynny udział w liturgii niedzielnej i świątecznej. Praktykować ją mieli przez codzienną modlitwę i rachunek sumienia, częstą spowiedź i przystępowanie do Komunii św. Pomocą w rozwoju wiary miało być nauczenie się na pamięć małego katechizmu i częste zachęty do dobrego życia. Wśród koniecznych zasad kierownictwa podkreślano, że młodzież musi być uczona w różnych grupach, w zależności od posiadanych zdolności i pojętności. Przystosowane do wieku uczniów lekcje i ćwiczenia, powinny prowadzić do postępu w pozyskanej wiedzy. Sprawdzianem pilności uczniowskiej i pracy nauczycielskiej miały być cosobotnie dysputy uczniowskie obejmujące poznany w ciągu ostatnich dni materiał. Zwracano uwagę, że kary za opieszałość w nauce i złe zachowanie powinny być stosowane z umiarem, by nie obrzydzić uczniom nauki na całe życie. Co do sposobów uczenia profesorowie wszechnicy krakowskiej dawali szczegółowy plan zajęć oraz polecili do każdego przedmiotu odpowiednie podręczniki ${ }^{65}$.

Owocem synodu bp. M. Szyszkowskiego było wydanie Reformationes generales, zawierającego całościowy plan przystosowania procedur administracyjnych i duszpasterstwa w diecezji krakowskiej do postanowień Soboru Trydenckiego. Sprawom szkolnym poświęcony był obszerny statut $13^{66}$.

W diecezji krakowskiej na przełomie XVI i XVII stulecia 92\% parafii posiadało szkołę. Badacze uznają tę liczbę za minimalną, biorąc pod uwagę, że dla części parafii brakuje źródeł ${ }^{67}$. W rozległej diecezji nie wszędzie było tak dobrze. W podgórskich i wschodnich dekanatach odsetek parafii, gdzie funkcjonowały szkoły był mniejszy. Zdaniem E. Wiśniowskiego w pierwszej połowie XVI w. na terenie archidiakonatu lubelskiego szkoły były w $75 \%$ parafii. Wspomniane wyżej działania promujące szkołę przyniosły jednak rezultat. $\mathrm{W}$ trakcie wizytacji w $1603 \mathrm{r}$. w na tym samym obszarze odnotowano istnienie szkoły w 88\% parafiach $^{68}$. W 1637 r. w dekanacie urzędowskim szkoły nie było tylko w 2 lub 3 parafiach (z 21 istniejących). W Radzięcinie i Wysokich kościół był zajęty przez kalwinów, a wizytacja w Targowiskach nie miała miejsca lub nie zachował się z niej protokół ${ }^{69}$.

W drugiej połowie XVII w. działalność edukacyjna w Kraśniku była mocno utrudniona z powodu wojen, pożarów i epidemii. Serię nieszczęść rozpoczął wielki pożar miasta, który 9 czerwca $1637 \mathrm{r}$. całkowicie strawił drewniane miasto i murowany kościół z klasztorem ${ }^{70}$. Ledwie zdołano usunąc zniszczenia ${ }^{71}$, w trakcie buntu

65 S. Kot, Szkolnictwo parafialne..., dz. cyt., s. 52-56.

66 B. Kumor, Dzieje diecezji..., dz. cyt., s. 115.

67 S. Kot, Szkolnictwo parafialne..., dz. cyt., s. 123-389; S. Litak, Edukacja poczatkowa ..., dz. cyt., s. 60-61.

68 S. Litak, Edukacja poczatkowa..., dz. cyt., s. 63.

${ }^{69}$ AKMKr, sygn. AV Cap 44, k. 19, 24v, 33, 47, 49, 51, 53, 55, 567, 60v, 64v, 69, 76v, 85, $86 \mathrm{v}, 87,88 \mathrm{v}, 94 \mathrm{v}$.

70 APKr, sygn. U 1629-1670, k. 40.

71 Powstałe wówczas wyposażenie opisała A. S. Czyż, Program ikonograficzny wystroju 
Chmielnickiego, 20 listopada 1648 r. miasto zostało po raz wtóry obrócone w perzynę. Kozacy zrabowali kościół i zabudowania klasztorne, spalili ok. 70 domów i zabili ok. 300 mieszkańców ${ }^{72}$. Cztery lata później mieszkańców dziesiątkowało morowe powietrze $^{73}$. W czasie ,potopu" szwedzkiego miasto całkowicie się wyludniło. Klasztor i kościół zostały obrabowane. Kozacy i Szwedzi spalili dach nad kościołem, w wyniku czego zawalił się również jeden z szczytów świątyni. Kanonicy schronili się wówczas w twierdzy zamojskiej ${ }^{74}$. Po zakończeniu działań wojennych miasto zostało odbudowane. Spokój nie trwał jednak długo. Po raz czwarty miasto całkowicie się spaliło 24 grudnia 1677 r. Pożar zniszczył także kościół i zabudowania klasztorne ${ }^{75}$.

Podnoszenie z ruin kościoła i klasztoru nie było łatwe. Bieda po wojnach kozackich, szwedzkich i moskiewskich była powszechna. Do 1689 r. kanonicy nie zdołali odbudować kościoła. W tymże roku wizytator biskupi upomniał prepozyta Jerzego Grzegorza Górskiego, by dokończył renowacji świątyni. Na nic zdały się ponaglenia, skoro osiem lat później, w 1697 r., trzeci z kolei prepozyt Possydoniusz Fiołko Gryglewicz zrezygnował z urzędu, uzasadniając władzom zakonu swoją decyzję trudnościami materialnymi klasztoru ${ }^{76}$.

Nie wiemy, czy za każdym razem odbudowa miasta i klasztoru automatycznie pociągała za sobą renowację starego lub wzniesienie nowego budynku szkolnego. Pewne jest, że reaktywowano zajęcia szkolne. Świadczą o tym nieliczne zapisy źródłowe. W nekrologu kanoników i dobroczyńców znajdujemy wzmiankę, że zmarły w 1706 r. Paweł Pajęcki uczęszczał do szkoły w Kraśniku. Musiało to być w połowie lat 70. XVII stulecia, skoro w tym roku wstąpił do tutejszego klasztoru ${ }^{77}$.

W latach 80. siedemnastego stulecia, mimo wspomnianych trudności ekonomicznych klasztor prowadził szkołę ${ }^{78}$. Istniał wówczas osobny dom dla nauczyciela. W protokołach z poprzedniej wizytacji w 1682 r. zapisano polecenie dokończenia jego budowy ${ }^{79}$.

Wiek XVIII przyniósł miastu nowe klęski. W czasie wojny północnej mieszkańcy Kraśnika zmuszeni byli ponosić koszty utrzymania stacjonujących w mieście

wnętrza kościoła pw. Wniebowzięcia Najświętszej Maryi Panny i św. Augustyna w Kraśniku (wiek XVII I XVIII), ABMK 108 (2017), s. 63-98.

72 I. Makarczyk, Kraśnik - klasztor, miasto i parafia w kronikach Stefana Renatowicza oraz Benedykta Samotulskiego, „Echa Przeszłości” 16 (2015), s. 83-84.

73 APKr, sygn. U 1629-1670, k. 113.

74 ABC, Acta Capituli Generalis Conventus Sacratissimi Corporis Christi Casimiriae ad Cracoviam Canonicorum Regularium Sancti Augustini (1628-1779), b. sygn.

75 I. Makarczyk, Kraśnik - klasztor..., dz. cyt., s. 85.

76 ABC, Acta Capituli Generalis Conventus Sacratissimi Corporis Christi Casimiriae ad Cracoviam Canonicorum Regularium Sancti Augustini (1628-1779), b. sygn.

77 ABC, Memoriale Fratrum et Benefactorum defunctorum Congregationis Canonicorum Regularium Lateranensium, b. sygn.

78 AKMKr, sygn. AVCap. 66, k. 53.

79 AKMKr, sygn. AV 12, k. 95. 
wojsk rosyjskich ${ }^{80}$. W 1717 r. wojska saskie zniszczyły miasto, zabijając przy tym brata zakonnego Macieja Wodzickiego ${ }^{81}$. Tym razem niszczenie miasta nie pociągnęło za sobą zniszczenia szkoły i domu dla nauczyciela. W 1718 r. wizytator biskupi zastaje obydwa budynki w dobrym stanie ${ }^{82}$. Szkoła wówczas funkcjonowała, skoro wizytator zaznaczył, że ówczesny bakałarz Antoni Wilgocki uczył w niej od dwóch lat ${ }^{83}$.

Sytuacja radykalnie się zmieniła po kolejnym pożarze miasta, który wybuchł 1 czerwca 1735 r. Ogień zniszczył miasto, kościół i wszystkie zabudowania klasztorne ${ }^{84}$. Ówczesny prepozyt Andrzej Kordacki niewiele zrobił dla odbudowy kościoła i klasztoru z braku pieniędzy, wyludnienia miasta (brak rąk do pracy) i głodu. Za brak postępów w odbudowie prepozyt został złożony z urzędu ${ }^{85}$. Brak funduszy na odbudowę był tak dotkliwy, że kolejny prepozyt Tomasz Banaszewski wykorzystał w tym celu pieniądze bractwa przykościelnego, które z tego powodu w 1746 r. wniosło przeciw niemu oskarżenie ${ }^{86}$. Kościół i klasztor zostały odbudowane za rządów następnego prepozyta Jakuba Melaniusza Małaczyńskiego. Prowadzone przez niego prace, rozpoczęte w 1746 r., zostały zakończone dopiero w $1758 \mathrm{r}^{87}$

W tym okresie szkoła już nie działała. Wizytacja przeprowadzona w 1748 r. wykazała, że przy parafii nie prowadzono szkoły. Odbudowa, zdaniem wizytatora, nie była łatwa, skoro wyznaczył prepozytowi dwa lata na otwarcie szkoły ${ }^{88}$.

W tymże czasie brak szkoły w Kraśniku nie był czymś wyjątkowym. Dzięki Tabelom Załuskiego, sporządzonym w latach 1747-1749 (uzupełnionym o inne źródła dla 2 dekanatów krakowskich i 4 dekanatów wiejskich), wiemy, że w diecezji krakowskiej szkoły funkcjonowały w 273 z 765 parafii, dla których posiadamy źródła (ok. 36\%). W archidiakonacie lubelskiem (5 dekanatów: Chodel, Kazimierz, Łuków, Parczew, Solec) było 25 szkół na 78 parafii (32\%), a w archidiakonacie zawichojskim (3 dekanaty: Opatów, Urzędów, Zawichost) - 12 szkół na 41 parafii $(29 \%)^{89}$.

${ }_{80}$ APL, AMK, sygn. 28, k. 12v.

81 ABC, Memoriale Fratrum et Benefactorum defunctorum Congregationis Canonicorum Regularium Lateranensium, b. sygn.

82 AKMKr, sygn. AVCap. 58, k. 48.

${ }^{83}$ AKMKr, sygn. AVCap. 58, k. 51.

${ }^{84}$ ABC, Memoriale Fratrum et Benefactorum defunctorum Congregationis Canonicorum Regularium Lateranensium, b. sygn., s. 152

85 ABC, Acta Capituli Generalis Conventus Sacratissimi Corporis Christi Casimiriae ad Cracoviam Canonicorum Regularium Sancti Augustini (1628-1779), b. sygn.

86 Tamże.

${ }^{87}$ ABC, Memoriale Fratrum et benefactorum defunctorum Congregationis Canonicorum Regularium Lateranensium, b. sygn.; ABC, Acta Capituli Generalis Conventus Sacratissimi Corporis Christi Casimiriae ad Cracoviam Canonicorum Regularium Sancti Augustini (1628-1779); ABC, Liber visitationum Conventuum (1692-1697), b. sygn.

88 AKMKr, sygn. AV 45, k. 185v.

89 S. Litak, Edukacja początkowa..., dz. cyt., s. 103-106; S. Litak, Struktura i funkcje parafii w Polsce, w: Kościół w Polsce, t. 2, red. J. Kłoczowski, Kraków 1970, s. 388-390. 
W dekanacie urzędowskim szkoły funkcjonowały w 3 parafiach miejskich i 3 wiejskich z 21 parafii wchodzących w skład dekanatu (28,5\%). Szkoły były w: Białej, Borowie, Goraju, Rachowie (Annopolu), Urzędowie i Zaklikowie ${ }^{90}$.

Brak szkoły w $1748 \mathrm{r}$. był przejściowy i uzasadniony raczej zniszczeniem zabudowy klasztornej i trudną sytuacją finansową wspólnoty zakonnej starającej się odbudować klasztor. Widoczna wówczas zapaść w szkolnictwie parafialnym mogła być usprawiedliwieniem dla nie dość gorliwych starań o otwarcie szkoły. O okresowym jedynie braku szkoły świadczy to, że w 1765 r. w księdze brackiej występuje nauczyciel szkoły Stanisław Wierzbicki, który pełnił także obowiązki organisty i pisarza brackiego ${ }^{91}$.

Upadek szkolnictwa parafialnego rozpoczął się po drugiej wojnie północnej (1655-1660). Pogłębił się jeszcze po wielkiej wojnie północnej (1700-1721). Przyczynę takiego stanu upatruje się w zniszczeniach wojennych, znacznym zmniejszeniu liczby mieszkańców - ofiar wojny, zaraz i głodu oraz upadku gospodarczym państwa. Kryzys finansowy, związany ze spadkiem wartości pieniądza, spowodował obniżenie dochodów majątków szlacheckich i kościelnych. Zubożenie społeczeństwa, szczególnie plebanów i kolatorów kościołów, w wielu przypadkach utrudniało dbałość o budynki szkole i uniemożliwiało zatrudnienie wykwalifikowanych nauczycieli92. Rację ma ks. Andrzej Zapart twierdząc, że zmniejszenie funduszy kościelnych i powszechna bieda zmusiła plebanów do wyboru, czy łożyć na szkołę parafialną, czy dbać o przytułki dla ubogich. Wybór nie był trudny, tym bardziej, że szlachta coraz bardziej nie widziała potrzeby utrzymywania szkółek dla dzieci chłopskich i mieszczańskich, własne posyłając do szkół zakonnych ${ }^{93}$. Chłopi również nie naciskali na plebanów i właściciel wsi, by utrzymywali szkoły. Sami przestali widzieć potrzebę posyłania swoich dzieci do szkół. Zwiększone powinności pańszczyźniane oraz bieda skłaniała raczej do wykorzystania każdej pary rąk do pracy, niż popierania nauki wła-

90 AKMKr, [Tabellae ecclesiarum.] Decanatus: Opatoviensis,Urzędoviensis, Zawichostensis, archidiaconatus Zawichostensis (dalej: Tabele Załuskiego 2), k. 8-26.

91 APKr, Księga Archikonfraterni Różańca Najświętszej Maryi Panny w Kościele Kraśnickim Canonicorum Regularium Lateranensium erygowanej pod tytułem Wniebowzięcia tejże Królowej po zgorzeniu pomnienionego Kościoła sporządzona a dla pomnożenia chwały Boskiej, honoru Maryi i pożytku żywych i umarłych. Otworzona Roku 1736 dnia 27 maja, b. sygn., (zapis z 13 X 1765 r.).

92 H. Błażkiewicz, Szkolnictwo parafialne $w$ diecezji przemyskiej $w$ latach 1603-1757 w świetle wizytacji biskupich, „Nasza Przeszłość” 46 (1976), s. 166-169; H. Karbowiak, Szkolnictwo elementarne na terenie archidiakonatu warszawskiego $w$ przedrozbiorowej Polsce, „Studia Płockie” 21 (1993), s. 128-129; S. Litak, Edukacja poczatkowa ..., dz. cyt., s. 69-70, 79, 131-132; J. Ryś, z dziejów szkoły parafialnej w Myślenicach, „Annales Academiae Paedagogicae Cracoviensis. Studia Historica” 21 (2004), z. 3, Księga jubileuszowa Profesora Feliksa Kiryka, s. 455-456; P. Ziółkowski, Dzieje szkolnictwa na polskiej wsi na przestrzeni wieków, „Ukraińska Polonistyka” 17 (2014), s. 163.

93 A. Zapart, Szkolnictwo parafialne w archidiakonacie krakowskim od XVI do XVIII wieku, Lublin 1983, s. 99-102. 
snych dzieci, i tak pozbawionych możliwości awansu społecznego ${ }^{94}$. Tak nakreśloną sytuację potwierdzają protokoły powizytacyjne. Na 21 parafii w dekanacie urzędowskim szpitale były w 18. Brakowało ich jedynie w Prawnie, Radomyślu i Radzięcinie. Utrzymywano w nich 120 ubogich $^{95}$. Szkółki utrzymywane były jedynie w 6 parafiach, jak wyżej wspomniano, a liczba uczniów była wielokrotnie niższa. Taka sytuacja przetrwała aż do pierwszego rozbioru Rzeczpospolitej.

Znaczniejsze reformy szkolnictwa parafialnego zaplanowali i starali się wdrożyć w życie dopiero działacze Komisji Edukacji Narodowej, choć już wcześniej znaleźli się duchowni i pedagodzy, którzy widzieli konieczność edukacji stanów niższych ${ }^{96}$. Wielu z nich w sprawie nauczania dzieci i młodzieży wszystkich stanów podzielało poglądy bp. Michała Jerzego Poniatowskiego, ówczesnego ordynariusza płockiego. Pisał on: „,óż może być świętszego i pożyteczniejszego tak dla Kościoła, jako dla kraju nad ćwiczenie młodzi zaraz od ich dzieciństwa, nie tylko w katechizmie i w rzeczach tyczących się religii i obyczajów, ale też dla każdej kondycji ludzi przez cały przeciąg życia najpotrzebniejszych, jakie są umieć czytać, pisać, rachować, i pospolitsze reguły wymiaru?"97.

Szkoły parafialne miały być najniższym szczeblem szkolnictwa narodowego. W podstawowym dokumencie organizacyjnym szkolnictwa polskiego tzw. „Ustawach Komisji Edukacji Narodowej dla stanu akademickiego” czytamy: „Szkółki po miasteczkach i wsiach, bądź bliskie kościołów parafialnych, bądź dalekie od nich, pod imieniem szkół parafialnych zawierają się. Jedne z nich, zwłaszcza w miasteczkach, mogą być większe, to jest więcej nauk zamykające, inne, w których mniej nauk będzie, mniejszymi nazwane" ${ }^{98}$.

Choć prowadzenie ich zostawiono w rękach duchowieństwa, było jasne, że szkoły te nie będą kształcić dzieci i młodzieży wyłącznie na potrzeby Kościoła. Więcej nawet, zdawano sobie sprawę, że większość absolwentów nie wybierze drogi do kapłaństwa lub życia zakonnego. Chciano polskie szkoły parafialne upodobnić do pruskiego nowoczesnego szkolnictwa powszechnego, kształcącego mieszkańców miast i wsi na wykwalifikowanych pracowników w rzemiośle, handlu i rolnictwie.

94 H. Kołłątaj, Stan oświecenia w Polsce w ostatnich latach panowania Augusta III (1750-1764), Warszawa 1905, s. 68-69; M. Krupa, Szkoła parafialna Komisji Edukacji Narodowej a szkoła ludowa w Prusach i Austrii, „Rocznik Lubelski” 15 (1972), s. 58-61; S. Litak, Edukacja początkowa ..., dz. cyt., s. 132; T. Wierzbowski, Szkoły parafialne w Polsce i na Litwie za czasów Komisji Edukacji Narodowej 1773-1794, Kraków 1921, s. 17-19; M. Przedpełski, Oświata w powiecie sierpeckim w XV do XX w., ,Rocznik Mazowiecki” 4 (1972), s. 301-302.

95 AKMKr, sygn. AV 45, k. 68, 70, 72, 74v, 76, 79-79v, 82, 85, 89, 91-91v, 93v, 98v, 100v, 103, 105v-106, 108, 109v, 111v, 113v, 115v; AKMKr, Tabele Załuskiego 2, k. 8-26.

96 T. Wierzbowski, Szkoty parafialne..., dz. cyt., s. 9-11.

${ }_{97}$ Rozrządzenia y pisma pasterskie za rządów J.O. Xięcia JMCI Michała Jerzego Poniatowskiego biskupa płockiego etc., ect., do diecezyi płockiey wydane, t. 1, Warszawa 1785, s. 480-481.

98 Ustawy Komisji Edukacji Narodowej dla Stanu Akademickiego i na szkoty w krajach Rzeczypospolitej przepisane w Warszawie roku 1783, z przedmowa prof. Władysława Kucharskiego, Lwów 1923, s. 116. 
„Ustawy” wyraziły to w następujący sposób: „Oświecenie ludu około religii, około powinności stanu jego, około robót i przemysłu w tymże stanie, celem jest takowych szkółek. Każdy chętniej i dokładniej wykona obowiązki swoje, każdy lepiej odprawi robotę i rzemiosła, kiedy jako człowiek rozumny, prowadzony w nich będzie, kiedy go nauczą, jak i dla czego podległym mu być należy, jako dla pospolitego i swojego dobra ma używać władz duszy i ciała, które od Stwórcy odebrał" 99.

Mimo zaangażowania wielu osób nie udało się stworzyć trwałej sieci szkół parafialnych. Według badaczy w latach 1773-1794 w województwach koronnych otwarto 374 szkoły, ale większość funkcjonowała przez krótki okres. Zaledwie 50 z tych szkół było czynnych przez cały okres funkcjonowania Komisji Edukacji Narodowej ${ }^{100}$. Wśród powołanych wówczas do istnienia szkół parafialnych musiała być szkoła w Kraśniku, skoro w aktach Kapituły Generalnej z 10 grudnia 1798 r. znajdujemy informację, że w Kraśniku do szkoły uczęszczali ojcowie Melaniusz Józefski i Augustyn Pawlikowski ${ }^{101}$. Wizytowali tę szkołę prefekci lubelscy KEN w 1784, 1786, 1787 r., ale żadnej o niej nie pozostawili informacji ${ }^{102}$. Jedyne szczegółowe informacje pochodzą z wizytacji przeprowadzonej w $1781 \mathrm{r}$. przez ks. Franciszka Dunina Kozickiego, dziekana pilickiego, z polecenia bp. Kajetana Ignacego Sołtyka. Wówczas szkoła była utrzymywana w całości przez miasto. Z polecenia ordynata zamojskiego Andrzeja Hieronima Zamojskiego, dyrektor szkoły otrzymywał z kasy miasta 200 zł polskich. Bezpośredni nadzór nad szkołą i procesem edukacyjnym i wychowawczym należał do miejscowego prepozyta ${ }^{103}$.

Ważne i trwałe zmiany w istnieniu i funkcjonowaniu szkół parafialnych pojawiły się dopiero pod koniec 1798 r. Powołane przez sejm, wojewódzkie, ziemskie i powiatowe Komisje porządkowe cywilno-wojskowe miały się zająć nadzorem nad szkolnictwem parafialnym. Obowiązkiem zakładania i prowadzenie szkół zostali obarczenie proboszczowie. Pod groźbą kary finansowej mieli oni obowiązek przesyłania do Komisji corocznego sprawozdania o stanie szkoły, programie, ilości uczniów i ich postępach w nauce ${ }^{104}$. Proboszcz w Kraśniku miał przesyłać takowe sprawozdanie do Komisji rezydującej w Lublinie ${ }^{105}$.

\footnotetext{
99 Ustawy Komisji..., dz. cyt., s. 116.

${ }^{100}$ S. Litak, Edukacja poczatkowa ..., dz. cyt., s. 147.

${ }^{101}$ ABC, Acta Capituli Generalis Conventus Sacratissimi Corporis Christi Casimiriae ad Cracoviam Canonicorum Regularium Sancti Augustini (1628-1779), b. sygn.

${ }^{102}$ T. Wierzbowski, Szkoty parafialne..., dz. cyt., s. 157.

${ }^{103}$ AAL, sygn. Rep. A 105, k. 682.

${ }^{104}$ Kommissye porzadkowe cywilno-woyskowe, województw, ziem i powiatów w Koronie, w: Volumina legum, t. 9, Kraków 1889, s. 156; P. Jędrzejewski, Szkolnictwo parafialne województwa krakowskiego w dobie Sejmu Wielkiego (1788-1792), w: Komisja Edukacji Narodowej kontekst historyczno-pedagogiczny, t. 3, red. K. Dormus, B. Popiołek, A. Chłosty-Sikorskiej, R. Ślęczki, Kraków 2014, s. 254-255; T. Mizia, Komisje porządkowe cywilno-wojskowe a szkolnictwo parafialne w okresie Sejmu Czteroletniego, „Rozprawy z Dziejów Oświaty” 6 (1963), s. 40, 47.

${ }^{105}$ Kommissye porzadkowe cywilno-woyskowe..., dz. cyt., s. 147.
} 


\section{Budynek szkolny i nauczyciele}

Budynki szkole w okresie staropolskim zazwyczaj spełniały potrójną rolę. Były miejscem pobierania nauki, mieszkaniem dla nauczyciela a czasami również tymczasową „bursą” dla dzieci pochodzących z odległych miejscowości ${ }^{106}$. Zdarzało się, że zabudowania szkolne składały się z dwóch domów. W jednym mieściła się właściwa szkoła, a w drugim mieszkał nauczyciel. W większości przypadków zabudowania były drewniane, pokryte strzechą lub gontem. Do rzadkości, nawet w miastach, należały budynki murowane ${ }^{107}$.

Na temat budynków szkolnych w Kraśniku w wizytacjach znajdujemy niewiele wzmianek. W wizytacji radziwiłłowskiej z 1592 r. zaznaczono, że szkoła była pokryta starym dachem ${ }^{108}$. Kolejna wizytacja, przeprowadzona w 1617 r. za rządów bp. M. Szyszkowskiego, dostarcza nieco więcej informacji. Budynek szkolny był murowany. Składał się z sieni, dwóch izb i trzech komór. Jedno z większych pomieszczeń zajmował kierownik szkoły, drugie było pomieszczeniem klasowym. Dach musiał zostać naprawiony, bo wizytator stwierdził, że szkoła była dobrze utrzymana ${ }^{109}$. Kolejne pożary zniszczyły ten budynek, skoro w wizytacjach z końca XVII stulecia jest mowa o drewnianej szkole. Odbudowana w połowie XVII stulecia szkoła nie była gmachem solidnym, ponieważ w 1689 r. wizytator postulował wzniesienie nowego budynku. Stary nie nadawał się do reparacji ${ }^{110}$. Kolejne przekazy milczą, czy kanonicy wywiązali się z zaleceń wizytującego.

W 1617 r. budynek szkoły w Kraśniku był najokazalszy w dekanacie. Dziekan kielecki Jakub Piasecki, wizytujący parafie dekanatu urzędowskiego, opisał wszystkie budynki szkolne. Tylko w Zaklikowie szkoła składała się z dwóch izb i dwóch komór (o jedną komorę mniej niż w Kraśniku) ${ }^{111}$. Szkoły w: Batorzu ${ }^{112}$, Białej ${ }^{113}$, Borowie ${ }^{114}$, Dzierzkowicach ${ }^{115}$, Goraju ${ }^{116}$, Gościeradowie ${ }^{117}$, Modliborzycach $^{118}$, Pniowie ${ }^{119}$, Potoku ${ }^{120}$, Popkowicach ${ }^{121}$, Świeciechowie ${ }^{122}$, Urzędo-

\footnotetext{
${ }^{106}$ S. Litak, Edukacja początkowa..., dz. cyt., s. 167.

${ }^{107}$ S. Litak, Edukacja poczatkowa..., dz. cyt., s. 169.

${ }^{108}$ AKMKr, sygn. AV 1, k. 33v.

${ }^{109}$ AKMKr, sygn. AVCap. 34, k. 14.

${ }^{110}$ AKMKr, sygn. AVCap. 66, s. 51, 53.

${ }^{111}$ AKMKr, sygn. AVCap. 34, k. 27v.

${ }^{112}$ AKMKr, sygn. AVCap. 34, k. 6.

${ }^{113}$ AKMKr, sygn. AVCap. 34, k. 8.

${ }^{114}$ AKMKr, sygn. AVCap. 34, k. 33v.

115 AKMKr, sygn. AVCap. 34, k. 22v.

${ }^{116}$ AKMKr, sygn. AVCap. 34, k. 25v.

${ }_{117}$ AKMKr, sygn. AVCap. 34, k. 24.

${ }_{118}$ AKMKr, sygn. AVCap. 34, k. 9v.

${ }^{119}$ AKMKr, sygn. AVCap. 34, k. 30v.

${ }^{120}$ AKMKr, sygn. AVCap. 34, k. 11v.

${ }^{121}$ AKMKr, sygn. AVCap. 34, k. 16v.

${ }^{122}$ AKMKr, sygn. AVCap. 34, k. 35.
} 
wie $^{123}$, Wrzawach ${ }^{124}$ i Zdziechowicach ${ }^{125}$ składały się z sieni, komory i jednej izby. Najmniejszą była szkoła w Targowiskach. Do pomieszczenia klasowego prowadziła sień ${ }^{126}$.

Jeszcze mniej informacji mamy o osobach zatrudnionych do nauczania dzieci. Wizytacje z lata 1598 i 1689 wspominają, że w szkole uczył jeden nauczyciel, nie podając ich nazwisk. W aktach miasta Kraśnika w pierwszej połowie XVII w. pojawiają się imiona i nazwiska bakałarzy. W 1607 r. był nim Jakub Golemowski, szczycący się tytułem kantora szkoły kraśnickiej ${ }^{127}$; w 1618 r. - Łukasz Kownacki, bakałarz ${ }^{128}$; w 1629 r. - Andrzej Bobrowski, pisarz miejski i rektor szkoły ${ }^{129}$; w latach 1630-1631 pochodzący z Kraśnika Marek Rybułkowicz, s. Wincentego, bakałarz gimnazjum kraśnickiego (baccalaureus Gimnazii Crasnicensis) ${ }^{130}$.

W 1638 r. rektorem szkoły był Franciszek Kwaterski, którego nazwisko znanym dzięki zapisowi sporządzonemu w 1638 r. w kraśnickiej księdze Archikonfraterni Różańca $\mathrm{NMP}^{131}$. Trzy lata później w tejże księdze odnotowano, że nauczycielem był Dominik Frankowicz, organista i pisarz bracki, występujący w tym charakterze w zapisach członków bractwa do 1659 r. ${ }^{132}$

Protokół z 1718 r. wizytacji przez archidiakona sandomierskiego Mikołaja Złotnickiego zawiera nazwiska dwóch nauczycieli: bakałarza Antoniego Wilgockiego i kantora Jakuba Gizińskiego ${ }^{133}$. Z innych zapisów tejże wizytacji można wnosić, że kantor kraśnicki uczył również w szkole. Przed upowszechnieniem organów w wielu parafiach byli kantorzy. Pełnili oni zazwyczaj rolę kierowników szkół lub tylko nauczycieli śpiewu ${ }^{134}$. W dekanacie urzędowskim w $1718 \mathrm{r}$. w czterech parafiach kantorzy byli równocześnie kierownikami szkoły. W Modli-

\footnotetext{
${ }^{123}$ AKMKr, sygn. AVCap. 34, k. 19v.

${ }^{124}$ AKMKr, sygn. AVCap. 34, k. 32.

${ }^{125}$ AKMKr, sygn. AVCap. 34, k. 2v.

${ }^{126}$ AKMKr, sygn. AVCap. 34, k. 4.

${ }^{127}$ APL, AMK, sygn. 7, k. 47.

${ }^{128}$ APL, AMK, sygn. 2, k. 238.

${ }^{129}$ APL, AMK, sygn. 2, k. 356v.

${ }^{130}$ APL, AMK, sygn. 8, k. 367v-368.

${ }^{131}$ APKr, Księga Archikonfraterni Różańca Najświętszej Maryi Panny w Kościele Kraśnickim Canonicorum Regularium Lateranensium erygowanej pod tytułem Wniebowzięcia tejże Królowej po zgorzeniu pomnienionego Kościoła sporządzona a dla pomnożenia chwały Boskiej, honoru Maryi i pożytku żywych i umarłych. Otworzona Roku 1736 dnia 27 maja, b. sygn., k. 4.

${ }^{132}$ APKr, Księga Archikonfraterni Różańca Najświętszej Maryi Panny w Kościele Kraśnickim Canonicorum Regularium Lateranensium erygowanej pod tytułem Wniebowzięcia tejże Królowej po zgorzeniu pomnienionego Kościoła sporządzona a dla pomnożenia chwały Boskiej, honoru Maryi i pożytku żywych i umarłych. Otworzona Roku 1736 dnia 27 maja, b. sygn., k. 4, zapis z 4 VII 1741.

${ }^{133}$ AKMKr, sygn. AVCap. 58, k. 51; S. Kot, Szkolnictwo parafialne..., dz. cyt., s. 230.

${ }^{134}$ S. Litak, Edukacja poczatkowa..., dz. cyt., s. 162.
} 
borzycach funkcje te łączył Józef Wolakiewicz ${ }^{135}$, w Urzędowie - Wojciech Kliszowski ${ }^{136}$, a w Zaklikowie - Szymon Rokicki ${ }^{137}$. W czterech parafiach byli tylko kierownicy szkół: we Wrzawach - bakałarz Jan Narolski ${ }^{138}$, Świeciechowie - Józef Kuderski ${ }^{139}$, Rybitwach - Paweł Lubecki ${ }^{140}$ i Dzierzkowicach - Szymon Sułakow$\mathrm{ski}^{141}$. W pozostałych parafiach byli organiści, ale przy żadnym z nich nie zapisano, że pełnili funkcję nauczycieli. Ponieważ w parafiach tych nie było najmniejszej wzmianki o szkole należy domniemywać z dużym prawdopodobieństwem, że szkoły w nich nie funkcjonowały.

W 1738 r. rektorem szkoły był organista Stanisław Lareciński ${ }^{142}$. W 1765 r. w księdze brackiej występuje nauczyciel szkoły Stanisław Wierzbicki, który pełnił także obowiązki organisty i pisarza brackiego ${ }^{143}$.

Dzięki informacjom z wizytacji radziwiłłowskiej z 1598 r. i wizytacji bp. Łubieńskiego z 1718 r. wiemy, że kierownik szkoły w Kraśniku otrzymywał od prepozyta wynagrodzenie w wysokości 24 florenów (złotych polskich) rocznie ${ }^{144}$. Ponadto na początku XVIII w. oprócz pensji miał od chłopów ordynację w zbożu i akcydensy z kościoła. Był to niski zarobek, świadczący o tym, że rektorat szkoły miejskiej nie był szczególnie intratnym zajęciem. Taka suma, nawet po zapewnieniu całodziennego wyżywienia i dachu nad głową, była mniejsza od zarobków urzędników miejskich w pobliskim Lublinie, w którym pisarz i szafarz (urzędnik zarządzający skarbem) pobierali kwartalnie 240 gr pensji, co w ciągu roku dawało im zarobek rzędu $32 z \mathrm{zp}^{145}$. Pensja taka świadczy ponadto, że kanonicy z jakiś powodów nie wynagradzali hojnie nauczyciela. Wówczas kantor w Kraśniku i kierownik szkoły w Świeciechowie otrzymywali 15 złp kwartalnie (bez dodatkowych akcydensów) ${ }^{146}$, a nauczyciel we Wrzawach wynagradzany był 17 złp kwartalnie i takimi samymi dodatkami, jak kierownik szkoły w Kraśniku ${ }^{147}$. Większą pensją niż kierownik szko-

${ }^{135}$ AKMKr, sygn. AVCap. 58, k. 17.

${ }^{136}$ AKMKr, sygn. AVCap. 58, k. 59.

${ }^{137}$ AKMKr, sygn. AVCap. 58, k. 12.

${ }^{138}$ AKMKr, sygn. AVCap. 58, k. 67.

${ }^{139}$ AKMKr, sygn. AVCap. 58, k. 77.

${ }^{140}$ AKMKr, sygn. AVCap. 58, k. 74.

${ }^{141}$ AKMKr, sygn. AVCap. 58, k. 65.

${ }^{142}$ APKr, Metrica baptisatorum ecclesiae collegiatae Conventus Crasnicensis Canonicorum Regularium Lateranensium post deflagrationem eiusdem ecclesiae 17353 junii, b. sygn., k. 4.

${ }^{143}$ APKr, Księga Archikonfraterni Różańca Najświętszej Maryi Panny w Kościele Kraśnickim Canonicorum Regularium Lateranensium erygowanej pod tytułem Wniebowzięcia tejże Królowej po zgorzeniu pomnienionego Kościoła sporządzona a dla pomnożenia chwały Boskiej, honoru Maryi i pożytku żywych i umarłych. Otworzona Roku 1736 dnia 27 maja (zapis z 13 X 1765 r.).

${ }^{144}$ AKMKr, sygn. AVCap. 12, k. 11; AKMKr, sygn. AVCap. 58, k. 51.

${ }^{145}$ W. Adamczyk, Ceny w Lublinie od XVI do końca XVIII wieku, Lwów 1935, s. 104.

${ }^{146}$ AKMKr, sygn. AVCap. 58, k. 51, 77.

${ }^{147}$ AKMKr, sygn. AVCap. 58, k. 67. 
ły w Kraśniku miał również w dekanacie urzędowskim kantor i kierownik szkoły w Zaklikowie. Kwartalnie otrzymywał $12 \mathrm{złp} \mathrm{i} 15 \mathrm{gr}^{148}$. Nie były to na ówczesne czasy sumy wielkie. Niemniej mieli stałe utrzymanie, na które nie wszyscy nauczyciele mogli liczyć. W tym samym dekanacie, w Białej, kierownikiem szkoły był pomocnik organisty w śpiewie Andrzej Tomolski. Utrzymywał się on z akcydensów i sam musiał zadbać o swoje ubranie ${ }^{149}$.

Generalnie zarobki pedagogów nie były wówczas wielkie. Możemy ocenić jego siłę nabywczą w porównaniu do zarobków i kosztów utrzymania w pobliskim Lublinie. Najwyższy poziom płac w Lublinie był na początku XVII w. W latach 1661-1670 płace pedagogów spadły o przeszło 50\%. Następnie powoli wzrastały aż do lat 1740-1750. Po tym okresie wzrostu, płace malały aż do końca Rzeczpospolitej ${ }^{150}$. Koszty utrzymania po „potopie” szwedzkim rosły aż do upadki Rzeczpospolitej. Najniższa siła kupna płac przypadała na trzy pierwsze dziesięciolecia XVIII $\mathrm{w}^{151}$. Badania kosztów utrzymania prowadzone przez międzywojennych historyków pokazały, że koszty utrzymania w okresie staropolskim rozkładały się w następujący sposób: $65 \%$ - żywność, $18 \%$ - odzież, 12\% mieszkanie, 5\% światło i opa $1^{152}$. Największym obciążeniem budżetu rodzinnego było pożywienie i ubranie. Pochłaniały one aż $83 \%$ zarobionych pieniędzy. Ceny żywności nieustannie wzrastały w dwóch pierwszych dziesięcioleciach XVIII w. Indeks żywnościowy wzrastał w okresie wojny. Drożyzna z powodu drugiej wojny północnej utrzymywała się jeszcze do 1720 r. Po krótkim okresie obniżenia cen i stabilizacji w latach $1741-1750$, ceny żywności osiągnęły maksymalny pułap ok. 1780 r. ${ }^{153}$ Takim samy mechanizmom podlegał wzrost cen odzieży. Najwięcej płacono za ubranie w latach 1711-1720 oraz 1780-1795. Ceny sukna i skór spadły tylko w latach $1730-1740^{154}$.

\section{Program nauki}

Tworzący szkoły parafialne i dbający o nie dobrze wówczas rozumieli, że były one podstawową pomocą w procesie nauczania i wychowania młodego pokolenia. Uczący się w nich, mili otrzymywać podstawowe narzędzi poznawcze kształtujące rozum i ducha: umiejętności czytania, pisania i rachowania oraz wskazanie zasad chrześcijańskiej moralności i dobrych obyczajów, opartych na pobożności i wiedzy religijnej. Cel ten starano się realizować przez odpowiedni program naukowy i wychowawczy, w którym istotnym elementem było poznanie prawd wiary, wprowa-

\footnotetext{
${ }^{148}$ AKMKr, sygn. AVCap. 58, k. 12.

${ }^{149}$ AKMKr, sygn. AVCap. 58, k. 27.

${ }^{150}$ W. Adamczyk, Ceny w Lublinie..., dz. cyt., s. 40.

${ }^{151}$ W. Adamczyk, Ceny w Lublinie..., dz. cyt., s. 53.

${ }^{152}$ W. Adamczyk, Ceny w Lublinie..., dz. cyt., s. 17.

${ }^{153}$ W. Adamczyk, Ceny $w$ Lublinie ..., dz. cyt., s. 33-34, 48.

${ }^{154}$ W. Adamczyk, Ceny w Lublinie..., dz. cyt., s. 35.
} 
dzenie w życie liturgiczne Kościoła oraz ćwiczenie pobożności (nauka katechizmu, czynne uczestnictwo w liturgii Kościoła przez posługę ministrancką i śpiew oraz formowanie sumienia przez sakramenty) ${ }^{155}$.

Historycy oświaty i szkolnictwa nie są zgodni, jak faktycznie wyglądała nauka w szkołach parafialnych. Jedni byli zdania, że uczono wyłącznie katechizmu, czytania oraz początków łaciny, a niekiedy pisania oraz rachunków. Inni utrzymywali, że uczono, poza katechizmem, czytania i pisania w języku ojczystym ${ }^{156}$. Łukasz Kurdybacha sądził, że w miejskich szkołach przerabiano program czterech niższych klas szkół jezuickich, a w szkołach wiejskich uczono czytania, pisana, gramatyki, śpiewu kościelnego, ministrantury, kalendarza kościelnego i elementów rachunków. Był jednak przekonany, że program był tak komponowany, by przygotować do „spełniania pomocniczej roli w nabożeństwach"157. S. Litak, podsumowując badania nad szkolnictwem parafialnym, był zdania, że pod koniec średniowiecza w Polsce, podobnie jak w Europie Zachodniej, uczniowie pamięciowo opanowywali podstawowe modlitwy i prawdy wiary, uczyli się włączać w liturgię przez poznanie ministrantury i śpiewu kościelnego oraz otrzymywali wykształcenie ogólne w zakresie czytania lub czytania i pisania. W okresie odrodzenia w ośrodkach miejskich, poza nauką katechizmu, program obejmował niepełne trivium, czasami poszerzanego o elementy quadrivium (arytmetykę, muzykę i naukę o kalendarzu), na wsiach ograniczano się do nauki czytania i pisania ${ }^{158}$.

Program w szkole kraśnickiej opierał się na trivium, podobnie jak w szkole parafialnej w przy klasztorze macierzystym w Kazimierzu i klasztorze w Kłodzku, z którego wywodzili się kanonicy kazimierscy. Minimum trzyletnie nauczanie obejmowało więc gramatykę, retorykę i dialektykę. Absolwenci tych szkół umieli czytać i pisać po łacinie oraz przyswoili sobie podstawową wiedzę z arytmetyki, geografii, historii, liturgii, muzyki i śpiewu kościelnego. W szkole dbano również o formację duchową uczniów, między innymi przez czynne uczestnictwo w liturgii i nabożeństwach sprawowanych w kościele klasztornym (śpiew w czasie nabożeństw i uczestnictwo w procesjach). Od 1612 r. program szkół w diecezji krakowskiej był zgodny z instrukcją Modus instituendae iuventutis bp. P. Tylickiego, przygotowanej przez profesorów uniwersyteckich na wniosek uczestników synodu diecezjalnego. W szkołach kanonickich program nauczania obejmował naukę gramatyki (kurs łaciny w oparciu o utwory Cycerona, Wergiliusza i Owidiusza),

${ }^{155}$ S. Litak, Struktura i funkcje parafii..., dz. cyt., s. 415; M. Różański, Szkoły parafialne w XVI-XVIII w. w archidiakonacie uniejowskim, Łódź 2013, s. 203-209.

${ }^{156}$ S. Kot, Szkolnictwo parafialne..., dz. cyt., s. 102; K. Kubik, Rozwój szkolnictwa wiejskiego do końca XVIII w., w: Dzieje szkolnictwa i oświaty na wsi polskiej do 1918 r., t. 1, red. S. Michalski, Warszawa 1982, s. 54-55; M. Różański, Szkoły parafialne..., dz. cyt., s. 209-211.

${ }^{157}$ Ł. Kurdybacha, Dzieje oświaty kościelnej do końca XVIII w., Warszawa 1949, s. 161-162.

${ }^{158}$ S. Litak, Edukacja początkowa..., dz. cyt., s. 201-208. 
retoryki, kaligrafii i stylistyki, śpiewu kościelnego, liturgii, katechizmu katolickiego (na podstawie katechizmów polskich Bellarmina lub Ledesmy), arytmetyki, historii powszechnej, historii ojczystej oraz innych. Nauka zapewne trwała, zgodnie $\mathrm{z}$ instrukcją bp. P. Tylickiego 8 godzin, 4 godziny przed południem i 4 godziny po południu. Tak jak w poprzednich wiekach uczniowie uczestniczyli ponadto w liturgii sprawowanej w kościele (Msza święta, Nieszpory, suplikacje, procesje, pogrzeby), a także organizowali misteria, które nazywano dialogami ${ }^{159}$.

W zachowanych źródłach o programie nauczania w szkole kanonickiej w Kraśniku jedyne informacje o programie, jakie posiadamy, zapisane są w aktach wizytacyjnych z lat $1589^{160}, 1637^{161}, 1682^{162}$ i $1689^{163}$. Dowiadujemy się z nich, że w szkole uczniowie uczyli się śpiewu i poznawali doktrynę. W wizytacji z 1682 r. sprecyzowano, że kształcenie naukowe dotyczyło poznania ,podstaw wiary i nauki”"164. Wskazuje to, że zasadniczym elementem programu, poza nauką śpiewu kościelnego, było poznanie katechizmu i ministrantury oraz nauka czytania i pisania wraz z początkami łaciny. Poziom nauki nie był wysoki, skoro sześć lat później wizytator nakazuje prepozytowi przyjąć ,jak najszybciej” „odpowiedniego” bakałarza ${ }^{165}$.

W okresie Komisji Edukacji Narodowej program szkół parafialnych był niezwykle ambitny. Polecano uczyć, prócz katechizmu i „nauki obyczajów”, czytania, pisania, jednostek metrycznych i monetarnych, higieny, podstawowych wiadomości z rolnictwa, ogrodnictwa i leczenia zwierząt oraz handlu ${ }^{166}$. Był on trudny do wprowadzenia, ze względu na niechęć do zmian starego programu oraz brak wykwalifikowanej kardy nauczycielskiej. Stąd w rozporządzeniu sejmowym o obowiązku prowadzenia szkół przez prepozytów i plebanów postawiono w tym względzie niższe wymagania. Poleca się, by „plebani, dla oświecenia uboższej szlachty i ciemnej prostoty przy parafii kościelnej chowali bakałarza, dla dania przynajmniej początkowej nauki młodzieży w nauczeniu ich czytać, pisać i rachunków"167.

${ }^{159}$ S. Kot., Szkolnictwo parafialne ..., dz. cyt., s. 39; J. Krukowski, Z dziejów szkolnictwa..., dz. cyt., s. 103-104; Z. Kuźniewska, Z dziejów szkół katolickich w Płocku i Polsce do XVII w., „Notatki Płockie” 2019, nr 2 (259), s. 5; K. Łatak, S. Nalbach, Ze studiów nad kultura umysłowa..., dz. cyt., s. 163-164; M. Różański, Szkoły parafialne..., dz. cyt., s. 209, 218, 228.

${ }^{160}$ AKMKr, sygn. AVCap. 66, k. 49.

${ }^{161}$ AKMKr, sygn. AVCap. 44, k. 33.

${ }^{162}$ AKMKr, sygn. AV 12, k. 95.

${ }^{163}$ AKMKr, sygn. AVCap. 55, k. 51.

${ }^{164}$ AKMKr, sygn. AV 12, k. 95.

${ }^{165}$ AKMKr, sygn. AVCap. 55, k. 51.

166 Ustawy Komisji..., dz. cyt., s. 118.

${ }^{167}$ Kommissye porzadkowe..., dz. cyt., s. 156. 


\section{Podsumowanie}

Historia szkoły parafialnej w Kraśniku w okresie staropolskim jest kolejnym potwierdzeniem, że elity państwowe, miejskie i kościelne generalnie widziały konieczność organizowania i utrzymywania szkół elementarnych przy parafiach, choć zbyt często zwalniały się z tego obowiązku ze względu na trudności ${ }^{168}$. A tych nie brakowało, szczególnie w XVII i XVIII stuleciu. Miasto było kilkakrotnie niszczone przez pożary i pustoszone przez obce wojska. Do tego dokładały się związane $\mathrm{z}$ tym trudności ekonomiczne oraz klęski głodu i zarazy. W takich okolicznościach dbałość o funkcjonowanie szkoły i zapewnienie godziwych warunków nauki i pracy dla uczniów i nauczycieli przegrywały $\mathrm{z}$ innymi ważnymi potrzebami. Dowodów na to nie brakuje nawet $\mathrm{w}$ tak niewielkim, zachowanym materiale źródłowym dotyczącym szkoły (brak źródeł do dziejów szkolnictwa polskiego do początków XIX w. jest regułą, a nie wyjątkiem). Istniejące wówczas w Rzeczpospolitej szkoły parafialne nie były duże. Jednorazowo w miejskich szkołach parafialnych uczyło się najwyżej dwie lub trzy dziesiątki uczniów, w różnym wieku. Zajęcia odbywały się do południa i po południu. Najwyżej trzyletni okres nauki był szerszy, niż w przypadku wiejskich szkół parafialnych. Było to związane z przyjęciem w szkołach prowadzonych przez kanoników regularnych zasady, że kształcenie obejmuje program trivium. Uczono więc gramatyki, retoryki, kaligrafii i stylistyki, śpiewu kościelnego, liturgii, katechizmu katolickiego i arytmetyki. Posyłanie dzieci do szkoły nie było czymś oczywistym, o czym świadczą kraśnickie księgi miejskie, w których odnajdujemy dokumenty sygnowane przez mieszczan i wiejskich mieszkańców przedmieść znakiem krzyża. Ten brak dbałości o edukację wśród mieszczan kraśnickich, pospólstwa miejskiego i chłopstwa zamieszkującego wsie parafii kraśnickiej zapewne potwierdziłyby kraśnickie księgi miejskie, przebadanie pod kątem umiejętności pisania mieszkańców Kraśnika i okolicy, zgodnie z metodologią wypracowaną przez Wacława Urbana ${ }^{169}$.

${ }^{168}$ Zob. J. Kracik, Niełatwe początki seminarium duchownego w Krakowie (w 375 rocznice założenia), ABMK 35 (1983), s. 231-246.

${ }^{169} \mathrm{~W}$. Urban, Umiejętność pisania na Lubelszczyźnie w XVII w., w: Problemy historii $i$ archiwistyki, red. T. Mencel, Lublin 1986, s. 57-68; W. Urban, Umiejętność pisania w Małopolsce w drugiej połowie XVI wieku, „Przegląd Historyczny” 68 (1977), t. 2, s. 231-257; W. Urban, Sztuka pisania w województwie krakowskim w XVII i XVIII wieku, „Przegląd Historyczny” 75 (1984), t. 1, s. 39-82; W. Urban, Tragedia kulturalna Polski. Umiejętność pisania $i$ czytania od połowy XVI do połowy XIX wieku, „Rocznik Biblioteki Naukowej PAU i PAN w Krakowie” 46 (2001), s. 165-174. 


\section{BIBLIOGRAFIA}

\section{Źródła archiwalne:}

\section{Archiwum Archidiecezjalne Lubelskie:}

sygn. Off. Lub. 2, Acta consistorii foranei Lublinensis dioecesis Cracoviensis (1452-1466).

sygn. Off. Lub. 4, Acta consistorii foranei Lublinensis dioecesis Cracoviensis (1465-1480).

sygn. Rep. A 105, Akta wizyty generalney w trzech dekanatach: chodelskim, urzędowskim y kazimirskim z woli y rozkazu Jaśnie Oświeconego Imci x. Kajetana Ignacego Sołtyka, biskupa krakowskiego, xiążęcia siewierskiego przez x. Franciszka Dunina Kozickiego, kollegiaty pileckiey dziekana od dnia 15 maja w roku 1781 poczętey, a w roku 1782 dniach ostatnich miesiąca stycznia odprawioney i dokończoney spisane.

\section{Archiwum Klasztoru Bożego Ciała Kanoników Regularnych Laterańskich w Krakowie:}

Acta Capituli Generalis Conventus Sacratissimi Corporis Christi Casimiriae ad Cracoviam Canonicorum Regularium Sancti Augustini (1628-1779).

Cathalogus fratrum defunctorum Canonicorum Regularium Lateranensium Congregationis Cracoviensis ab introductione Cracoviam scilicet ab anno 1405 conscriptus cui accedit.

Liber visitationum conventuum (1692-1697).

Memoriale fratrum et benefactorum defunctorum Congregationis Canonicorum Regularium Lateranensium.

\section{Archiwum Kurii Metropolitalnej w Krakowie:}

sygn. AV 1, Wizyta w archidyakonacie zawichojskim Andrzeja z Żarnowca, wik[ariusza] kolleg[iaty] sandomierskiej z r. 1592.

sygn. AV 12, Acta visitationum archidiaconatus Zavichostensis, id est decanatus Zavichostensis, Opatoviensis et Urzędoviensis, 1682.

sygn. AV 45, Archidiaconatus Zavichostensis, tres decanatus, videlicet: Urzędoviensem, Opatoviensem et Zavichostensem, in quibus ecclesiae parochiales numerant[ur] 45, complectens, sub felici regimine et auspiciis Celsissimi principis Ill[ust]r[issi]mi et $\mathrm{R}$ [everendissi]mi D[omin]i, D[omin]i Andrea Załuski, episcopi Cracoviensis, ducis Severiae, generali visitatione lustratus, per Cyprianum Josephum Langi UID in ecclesiae Cathedrali Cracoviensi, arcidiaconum Zawichostensem, canonicum Sandomirien[sem], praep[osi]tum Rakovien[sem], anno quo visitavit nos oriens ex alto 1748 . 
sygn. AVCap 12, Visitatio ecclesiarum in archidiaconatu Zavichostensi anno D[omini] 1598.

sygn. AVCap. 34, Acta visitation[um] exteriorum archidiaconatus Zawichosten[sis] opera commisaria R[evere]ndi D[omini] Jacobi Piaseczki decani Kielczen[sis], can[onici] Poznanien[sis] in anno D[omi]ni millesimo sexcen[tesimo] decimo septimo diebus junii et julii confecta. Cuius archidiaconatus ius visitandi iurisdictio archidiaconalis Sacris Canonibus inscripta in tribus decanatibus Urzędovien[si], Zawichosten[si] et Opatowien[si] si primaeva sua pot[est]ae et eredit[at]e ad ip$\mathrm{su}[\mathrm{m}]$ archidiaconu[m] Zawichosten[sem] $\mathrm{p}[\mathrm{ro}] \mathrm{t}[\mathrm{em}]$ por[e] spectare et $\mathrm{p}$ [er]inere dignoscit. decanat[um] sive sup[ra] nominati ordinem et numerum infra 1617.

sygn. AVCap 44, [Acta visitationum decanatuum: Urzędoviensis, Zawichostensis et Opatoviensis ad archidiaconatum Zawichostensem pertinentium autboritate Reverendi Domini Jacobi Zadzik, episcopi Cracoviensis, anno Domini 1637 peracta].

sygn. AVCap. 55, Visitatio externa archidiaconatus Zavichostensis anno Domini millesimo sexcentissimo octuagesimo nono.

sygn. AVCap 58, Visitatio interna et externa archidiaconatu[s] Zavichosten[sis] tres Urzędovien[sem], Zavichosten[sem], Opatovien[sem] decanatus in se continentis per Perillustrem et Ad[mo]dum R[evere]ndum Nicolaum a Złotniki Złotnicki Leopolien[sem] can[oni]cum, archidiaconum et officialem Sandomir[iensem] et Malice et Obrazow parochum, S[a]crae Sacrae R[egiae] M[aie]s[ta]tis S[e] $\mathrm{cr}[\mathrm{etar}] \mathrm{ium}$ et vigore commissionis inferius contentae visitatorem commissarium in anno 1718vo mensibus 9bri et 10bri inchoata ac in anno sequenti 1719 no feliciter continuata.

sygn. AVCap. 66, Visitatio externa archidiaconatus Zavichostensis, decanatum: Urzędovien[sis], Zawichosten[sis], et Opatovien[sis], anno Domini millesimo sextengesimo octogesimo nono in octobre, novembre, decembre expedita in qua iura ecclesiarum, proventus parochorum una cum descriptionibus ecclesiarum et aedificiorum, noviter et ante extructorum, connotata demonstratur, per Perillustrem at Ad[mod]um R[evere]ndum Christophorum de Dębica Dębicki, juris utriusruae licentiatum, canonicum et officialem Sandomiriensem, praepositum Stobnicen[sem], $\mathrm{S}[\mathrm{a}]$ crae Sacrae R[egiae] M[aie]s[ta]tis secretarium expedita per me vero Albertum Carolum Mrowczynski publicum Sacra Authoritate Apostolica consistorii Sandomiriensis notarium, visitatoris commissarii secretarium fideliter conscripta.

sygn. EO 1, In ecclesia cathedrali Cracoviensi tempore archidiaconatus R[evere] ndi Stanislai Crasinski, Cracoviensis archidiaconi examinis ordinandorum pars prima $1573-1589$.

sygn. EO 3, In ecclesia cathedrali Cracoviensi tempore archidiaconatus R[evere]ndi Stanislai Crasinski, Cracoviensis archidiaconi examinis ordinandorum pars tertia 1597-1614.

[Tabellae ecclesiarum.] Decanatus: Opatoviensis,Urzędoviensis, Zawichostensis, archidiaconatus Zawichostensis (Tabele Załuskiego 2). 


\section{Archiwum Parafii Farnej w Kraśniku:}

sygn. U 1629-1670, Metrica baptisatorum ecclesiae collegiatae Conventus Crasnicensis Canonicorum Regularium Lateranensium post deflagrationem eiusdem ecclesiae 1735, 3 junii.

Księga Archikonfraterni Różańca Najświętszej Maryi Panny w kościele kraśnickim Canonicorum Regularium Lateranensium erygowanej pod tytułem Wniebowzięcia tejże Królowej po zgorzeniu pomnienionego kościoła sporządzona a dla pomnożenia chwały Boskiej, honoru Maryi i pożytku żywych i umarłych. Otworzona roku 1736, dnia 27 maja.

\section{Archiwum Państwowe w Lublinie:}

\section{Akta miasta Kraśnika:}

sygn. 2, [Księga wójtowsko-ławnicza i burmistrzowsko-radziecka] (1558-1748).

sygn. 7, Acta controversiarum officii advocatialis et scabinalis (1606-1611).

sygn. 8, [Księga wieczysta wójtowsko-ławnicza] (1608-1647).

sygn. 28, Liber electionum miasta Kraśnika (1708-1768).

\section{Źródła drukowane:}

Joannis Dlugossii senioris canonici Cracoviensis Opera omnia, t. 9, Liber beneficiorum dioecesis Cracoviensis nunc primum e codice autographo editus, t. 3, Monasteria, opr. A. Przeździecki, Kraków 1864.

Kołłątaj H., Stan oświecenia w Polsce w ostatnich latach panowania Augusta III (1750-1764), Warszawa 1905.

Kommissye porządkowe cywilno-woyskowe, województw, ziem i powiatów w Koronie, w: Volumina legum, t. 9, Kraków 1889.

Księga dochodów beneficjów diecezji krakowskiej z roku 1529 (tzw. „Liber Retaxationum”), wyd. Z. Leszczyńska-Skrętowa, Wrocław-Warszawa 1968.

Księgi egzaminów do święceń $w$ diecezji krakowskiej z lat 1573-1614, opr. i wst. opatrzył Z. Pietrzyk, Kraków 1991.

Metryka Uniwersytetu Krakowskiego z lat 1400-1508, wyd. A. Gąsiorowski, T. Jurek, I. Skierska przy współpr. R. Grzesika, t. 1-2, Kraków 2004.

Metryka czyli album Uniwersytetu Krakowskiego z lat 1509-1551, wyd. A. Gąsiorowski, T. Jurek, I. Skierska, przy współpr. R. Grzesika, Warszawa 2010.

Rozrzadzenia y pisma pasterskie za rządów J.O. Xięcia JMCI Michała Jerzego Poniatowskiego biskupa płockiego etc., ect., do diecezyi płockiey wydane, t. 1, Warszawa 1785.

Ustawy Komisji Edukacji Narodowej dla Stanu Akademickiego i na szkoty w krajach Rzeczypospolitej przepisane w Warszawie roku 1783, z przedmowa prof. Władysława Kucharskiego, Lwów 1923. 


\section{Opracowania:}

Adamczyk W., Ceny w Lublinie od XVI do końca XVIII wieku, Lwów 1935.

Bielak W., Okoliczności fundacji klasztoru kanoników regularnych w Kraśniku, „Archiwa, Biblioteki i Muzea Kościelne" 108 (2017), s. 17-27.

Błażkiewicz H., Szkolnictwo parafialne w diecezji przemyskiej w latach 1603-1757 w świetle wizytacji biskupich, „Nasza Przeszłość” 46 (1976), s. 153-206.

Chachaj J., Zarys dziejów parafii Popkowice do początków XVII w., „Archiwa, Biblioteki i Muzea Kościelne" 110 (2018), s. 93-118.

Czyż A. S., Program ikonograficzny wystroju wnętrza kościoła pw. Wniebowzięcia Najświętszej Maryi Panny i św. Augustyna w Kraśniku (wiek XVII I XVIII), „Archiwa, Biblioteki i Muzea Kościelne" 108 (2017), s. 63-98.

Froch W., Dzieje szkoły lubelskiej przy kościele parafialnym św. Michała w XVXVIII w., Lublin 1999, s. 13-14.

Gliński T., Kanonicy regularni (bożeciołki) w opinii Dlugosza, w: Studia z dziejów Kościoła Bożego Ciała w Krakowie, red. Z. Jakubowski, Kraków 1977, s. 201, s. 189-204.

Gmitek H., Album studentów Akademii Zamojskiej 1595-1781, Warszawa 1994.

Gmitek H., Młodzież z woj. lubelskiego Akademii Zamojskiej (1595-1781). Próba ujęcia statystycznego, „Res Historica” 17 (2004), s. 147-149.

Graff T., Klasztor w Kraśniku w dziełach Jana Dlugosza, „Archiwa, Biblioteki i Muzea Kościelne" 108 (2017), s. 99-110.

Grocholski H., Wokót początków Kraśnika, w: Z dziejów powiatu kraśnickiego, red. K. Myśliński, J. J. Szaflik, Lublin 1963, s. 28-32.

Jędrzejewski P., Szkolnictwo parafialne województwa krakowskiego w dobie Sejmu Wielkiego (1788-1792), w: Komisja Edukacji Narodowej kontekst historyczno-pedagogiczny, red. K. Dormus, B. Popiołek, A. Chłosta-Sikorska, R. Ślęczka, t. 3, Kraków 2014, s. 251-278.

Karbowiak A., Dzieje wychowania i szkót w Polsce w wiekach średnich, t. 2, Petersburg 1903.

Karbowiak H., Szkolnictwo elementarne na terenie archidiakonatu warszawskiego w przedrozbiorowej Polsce, „Studia Płockie” 21 (1993), s. 127-136.

Kiryk F., Z badań nad urbanizacja Lubelszczyzny w dobie jagiellońskiej, „Rocznik Naukowo-Dydaktyczny. Prace Historyczne" 1972, z. 43, s. 93-167.

Kopera Ł. S., Nauczanie parafialne $w$ Mstowie w czasach staropolskich i podczas zaborów, w: Mstów. Miasto - klasztor - parafia na przestrzeni wieków, red. K. Łatak, Łomianki 2013, s. 31-58.

Kopera Ł. S., Szkolnictwo i opieka spoteczna u Kanoników Regularnych Laterańskich obediencji kłobuckiej, „Veritati et Caritati” 5 (2015), s. 261-286.

Kot S., Szkolnictwo parafialne w Matopolsce XVI-XVIII w., Lwów 1912. 
Krukowski J., Z dziejów szkolnictwa parafialnego Krakowa w okresie Odrodzenia, Kraków 1986.

Krupa M., Szkoła parafialna Komisji Edukacji Narodowej a szkoła ludowa w Prusach i Austrii, „Rocznik Lubelski” 15 (1972), s. 57-78.

Kubik K., Rozwój szkolnictwa wiejskiego do końca XVIII w., w: Dzieje szkolnictwa i oświaty na wsi polskiej do 1918 r., red. S. Michalski, t. 1, Warszawa 1982, s. $28-95$.

Kudrybacha Ł., Dzieje oświaty kościelnej do końca XVIII w., Warszawa 1949.

Kumor B., Dzieje diecezji krakowskiej do 1795, t. 2, Kraków 1999, s. 148.

Kuraś S., Stownik historyczno-geograficzny województwa lubelskiego w średniowieczu, w: Dzieje Lubelszczyzny, t. 3, red. M. Wawrzyniak, Warszawa 1983.

Kuźniewska Z., Z dziejów szkót katolickich w Ptocku i Polsce do XVII w., „Notatki Płockie" 2019, nr 2 (259), s. 7-10.

Landecka H., Kościót parafialny pod wezwaniem Wniebowzięcia Najświętszej Maryi Panny w Kraśniku - nowe ustalenia badawcze po I etapie badań - 2008-2009, „Budownictwo i Architektura” 7 (2010), s. 53-66.

Litak S., Edukacja początkowa w polskich szkołach w XIII-XVIII wieku, Lublin 2010.

Litak S., Sieć szkót parafialnych w Rzeczpospolitej w XVI i pierwszej połowie XVII w. Próba posumowania., „Rozprawy z Dziejów Oświaty” 37 (1996), s. 21-35.

Litak S., Struktura i funkcje parafii w Polsce, w: Kościót w Polsce, t. 2, red. J. Kłoczowski, Kraków 1970, s. 259-481.

Łatak K., Kongregacja krakowska kanoników regularnych laterańskich na przestrzeni dziejów, Kraków 2002.

Łatak K., Nalbach S., Ze studiów nad kultura umystowa kanoników regularnych krakowskiej prepozytury Bożego Ciata w XV i XVI wieku, Kraków 2009.

Łatak K., Pęgier M., Kronika Stefana Renatowicza. Studium historyczno-źródłoznawcze, Łomianki 2017.

Łatak K., Prepozyci prepozytury kraśnickiej kanoników regularnych laterańskich od fundacji do reformy w 1628 roku, „Saeculum Christianum” 24 (2014), s. 139-161.

Łatak K., Szkoły parafialne kanoników regularnych laterańskich w Małopolsce w czasach staropolskich, „Nasza Przeszłość” 117 (2012), s. 351-380.

Makarczyk Irena, Kraśnik - klasztor, miasto i parafia w kronikach Stefana Renatowicza oraz Benedykta Samotulskiego, „Echa Przeszłości” 16 (2015), s. 79-90.

Mizia T., Komisje porzadkowe cywilno-wojskowe a szkolnictwo parafialne w okresie Sejmu Czteroletniego, „Rozprawy z Dziejów Oświaty” 6 (1963), s. 40-92.

Nasiorowski S., ,List pasterski” kard. Bernarda Maciejowskiego, Lublin 1992.

Nowacki J., Dzieje archidiecezji poznańskiej, t. 2, Archidiecezja poznańska w granicach historycznych i jej rozwój, Poznań 1964. 
Podedworny I., Nauczanie w klasztorze kanoników regularnych w Mstowie na przełomie średniowiecza i czasów nowożytnych, w: Przemijanie i trwanie. Kanonicy Regularni Laterańscy w dawnej i wspótczesnej Polsce, red. K. Łatak, I. Makarczyk, Kraków 2008, s. 451-464.

Przedpełski M., Oświata w powiecie sierpeckim w XV do XX w., „Rocznik Mazowiecki" 4 (1972), s. 293-363.

Różański M., Szkoły parafialne w XVI-XVIII w. $w$ archidiakonacie uniejowskim, Łódź 2013.

Ryś J., Z dziejów szkoty parafialnej w Myślenicach, „Annales Academiae Paedagogicae Cracoviensis. Studia Historica" 21 (2004), z. 3, s. 453-458.

Szczepaniak J., Duchowieństwo diecezji krakowskiej w XVIII w. Studium prozopograficzne, Kraków 2010.

Wierzbowski T., Szkoły parafialne w Polsce i na Litwie za czasów Komisji Edukacji Narodowej 1773-1794, Kraków 1921.

Wiśniowski E., Parafia w średniowiecznej Polsce. Struktura i funkcje społeczne, Lublin 2004.

Wiśniowski E., Rozwój organizacji parafialnej w Polsce do czasów reformacji, w: Kościół w Polsce, t. 1, Średniowiecze, red. J. Kłoczowski, Kraków 1966, s. 333-346.

Wiśniowski E., Sieć szkót parafialnych w Wielkopolsce i Małopolsce w początkach XVI w., „Roczniki Humanistyczne” 15 (1967), z. 2, s. 87-105.

Wojtyska H. D., Duchowość Kanoników Regularnych, „Saeculum Christianum” 3 (1996), nr 1, s. 125-130.

Zielińska E., Fidelia Fideis. Klasztor Kanoników Regularnych w Kraśniku a klasztor Kanoników Regularnych w Kazimierzu $w$ drugiej połowie XV i pierwszej połowie XVI wieku, w: Klasztor Bożego Ciała Kanoników Regularnych Laterańskich $w$ Krakowie w okresie przedtrydenckim. Ludzie - wydarzenia - budowle - kultu$r a$, red. K. Łatak, Łomianki 2012, s. 365-377.

Zielińska E., Kultura intelektualna kanoników regularnych z klasztoru w Kraśniku w latach 1469-1563, Lublin 2002.

Ziółkowski P., Dzieje szkolnictwa na polskiej wsi na przestrzeni wieków, „Ukraińska Polonistyka" 17 (2014), s. 159-177.

Urban W., Umiejętność pisania na Lubelszczyźnie w XVII w., w: Problemy historii $i$ archiwistyki, red. T. Mencel, Lublin 1986, s. 57-68.

Urban W., Umiejętność pisania w Małopolsce w drugiej połowie XVI wieku, „Przegląd Historyczny" 68 (1977), t. 2, s. 231-257.

Urban W., Sztuka pisania w województwie krakowskim w XVII i XVIII wieku, „Przegląd Historyczny" 75 (1984), t. 1, s. 39-82. 
Urban W., Tragedia kulturalna Polski. Umiejętność pisania i czytania od połowy XVI do połowy XIX wieku, ,Rocznik Biblioteki Naukowej PAU i PAN w Krakowie" 46 (2001), s. 165-174.

\section{Streszczenie}

Na przełomie XIV i XV w. Kraśnik, należący wówczas do Gorajskich a później Tęczyńskich, był znacznym ośrodkiem miejskim w niezbyt zaludnionym wschodnim obszarze woj. sandomierskiego (woj. lubelskie utworzono dopiero w 1474 r.). Istniała tam parafia pw. św. Piotra, a przy niej najprawdopodobniej szkoła parafialna. Po osadzeniu w mieście w 1468 r. kanoników regularnych laterańskich, z zasady dbających o prowadzenie szkół i organizowanie bibliotek, funkcjonowanie szkoły znajduje potwierdzenie w źródłach. Mimo licznych klęsk elementarnych rujnujących miasto (wojny, zarazy, głód), przynoszących zniszczenie zabudowy (z klasztorem i szkołą) oraz zastój gospodarczy i wyludnienie miasta szkoła nieprzerwanie działała, z wyjątkiem dwóch dziesięcioleci po wielkim pożarze miasta (1735 r.). Na początku XVII w. szkoła mieściła się w osobnym, murowanym budynku, który składał się z sieni, dwóch izb (klasa szkolna i mieszkanie nauczyciela) i trzech komór. Program w szkole kraśnickiej opierał się na trivium, podobnie jak w szkole parafialnej w przy klasztorze macierzystym w Kazimierzu i klasztorze w Kłodzku, z którego wywodzili się kanonicy kazimierscy. Minimum trzyletnie nauczanie obejmowało więc gramatykę, retorykę i dialektykę. Absolwenci tych szkół umieli czytać i pisać po łacinie oraz przyswajali sobie podstawową wiedzę z arytmetyki, geografii, historii, liturgii, muzyki i śpiewu kościelnego.

Słowa klucze: Kraśnik, kanonicy regularni laterańscy, szkoła parafialna

\section{The Parish School in Kraśnik in the Old Polish Period}

\section{Summary}

At the turn of the fourteenth and fifteenth centuries Kraśnik, then belonging to the Gorajski and later to Tęczyński, was a significant urban center in the lightly populated eastern area of the province. Sandomierski (Lubelskie Voivodeship was not established until 1474). The parish of St. Peter and probably a parish school next to it were there. The Canons Regular of the Lateran settled in the city in 1468 and, in principle, took care of the running of schools and organizing libraries. The functioning of the school is confirmed by sources. Despite numerous elementary calamities (wars, pestilence, famine) which ruined the city causing the destruction of buildings (including the monastery and school) as well as economic stagnation and depopulation of the city, the school operated continuously, except for two decades after the 
great fire of the city (1735). At the beginning of the 17th century, the school was located in a separate, brick building, which consisted of a hall, two rooms (school class and teacher's apartment) and three chambers. The program at the Kraśnik school was based on the trivium, like the parish school at the mother monastery in Kazimierz and the monastery in Kłodzko, from which Kazimierz canons came. At least three years of teaching included grammar, rhetoric and dialectics. Graduates of these schools were able to read and write in Latin and acquired basic knowledge of arithmetic, geography, history, liturgy, music and church singing.

Key words: Kraśnik, Canons Regular of the Lateran, parish school 